\title{
Identifying and targeting tumor-initiating cells in the treatment of breast cancer
}

\author{
Wei Wei ${ }^{1,2}$ and Michael T Lewis ${ }^{1,2,3}$ \\ ${ }^{1}$ Baylor College of Medicine, Lester and Sue Smith Breast Center, Houston, Texas, USA \\ Departments of ${ }^{2}$ Molecular and Cellular Biology, and ${ }^{3}$ Radiology, Baylor College of Medicine, \\ One Baylor Plaza, BCM600, Room N1210, Houston, Texas 77030, USA
}

Correspondence should be addressed to $\mathrm{M} T$ Lewis Email mtlewis@bcm.edu

\begin{abstract}
Breast cancer is the most common cancer in women (excluding skin cancer), and it is the second leading cause of cancer-related deaths. Although conventional and targeted therapies have improved survival rates, there are still considerable challenges in treating breast cancer, including treatment resistance, disease recurrence, and metastasis. Treatment resistance can be either de novo - because of traits that tumor cells possess before treatment - or acquired - because of traits that tumor cells gain in response to treatment. A recently proposed mechanism of de novo resistance invokes the existence of a specialized subset of cancer cells defined as tumor-initiating cells (TICS), or cancer stem cells (CSCS). TICs have the capacity to self-renew and to generate new tumors that consist entirely of clonally derived cell types present in the parental tumor. There are data to suggest that TICs are resistant to many conventional cancer therapies and that they can survive treatment in spite of dramatic shrinkage of the tumor. Residual TICs can then eventually regrow, which results in disease relapse. It has also been hypothesized that TIC may be responsible for metastatic disease. If these hypotheses are correct, targeting TICs may be imperative for achieving a cure. In the present review, we discuss evidence for breast TICS and their apparent resistance to conventional chemotherapy and radiotherapy as well as to various targeted therapies. We also address the potential impact of breast TIC plasticity and metastatic potential on therapeutic strategies. Finally, we describe several genes and signaling pathways that appear to be important for TIC function and may represent promising therapeutic targets.
\end{abstract}
Key Words
- cancer stem cells
- chemotherapy
- radiotherapy
- signaling pathways

Endocrine-Related Cancer (2015) 22, R135-R155

\section{Introduction}

In recent years, breast cancer patients, clinicians, and scientists have rightfully celebrated small, but significant, improvements in breast cancer outcome. These improvements have been attributed to better methods for early detection, enhanced screening efforts, and the availability of more effective targeted therapeutics for the treatment of the two largest clinically defined subtypes of breast cancers those that express the estrogen receptor $\left(\mathrm{ER}^{+}\right)$(with or without co-expression of the progesterone receptor (PR)) and those with overexpression or amplification of the human epidermal growth factor 2 (ErbB2) gene (a.k.a. HER2 ${ }^{+}$). These two subtypes of breast cancer account for $\sim 70$ and 15-20\% of all cases respectively. The remaining subtype, triple-negative breast cancer (TNBC), lacks expression of $\mathrm{ER}, \mathrm{PR}$, and HER2. To date, there are no targeted agents to combat TNBC, and its prognosis remains poor.

Published by Bioscientifica Ltd 
Despite recent progress, several major clinical problems remain. Chief among these are the issues of treatment resistance, disease recurrence, and metastasis. For example, whereas many $\mathrm{ER}^{+}$tumors respond to ER-targeted therapies (antiestrogens such as tamoxifen and aromatase inhibitors such as anastrozole, letrozole, and exemestane), de novo and acquired resistance is common (Burstein et al. 2014). Similarly, recent clinical trials have shown that up to $64 \%$ of HER2 ${ }^{+}$patients can show pathological complete response to combination treatment with dual anti-HER2 targeted therapy (Gianni et al. 2012, Schneeweiss et al. 2013, de Azambuja et al. 2014, Cortazar et al. 2014). However, a significant percentage of patients are resistant to these agents. In TNBC, treatment generally involves using multiagent chemotherapy along with surgery. Unfortunately, not all patients who receive chemotherapy show clinical benefit, and side effects can be significant. In the case of disease recurrence, the recurrent cancer can be refractory to the original treatment.

Breast cancer has long been recognized as a heterogeneous disease, and this heterogeneity has been invoked to explain, at least in part, differences in treatment response, recurrence potential, and metastatic behavior. Tumor heterogeneity exists at the histological and molecular levels within a single tumor (intratumoral) and between different tumors (intertumoral). Recent gene expression profiling is beginning to reveal the full extent of intertumoral heterogeneity. For example, independent of the three clinically defined subtypes of breast tumors, at least six molecular subtypes of breast cancer have been identified: luminal A, luminal B, HER2-enriched, normal-like, basal-like, and claudin-low (Perou et al. 2000, Herschkowitz et al. 2007). The luminal subtypes are generally $\mathrm{ER}^{+}$. The HER2-enriched subtypes are typically $\mathrm{ErbB}_{2}{ }^{+}$and are also generally $\mathrm{ER}^{-}$. Tumors in the basal-like subtype are generally triple-negative. To date, $\sim 60-70 \%$ of identified claudin-low tumors have been triple-negative (Prat \& Perou 2011). More recently, TNBC have been evaluated in large numbers and show at least six subclasses (Lehmann et al. 2011).

Although it has been less well studied than intertumoral heterogeneity has, breast tumors also show intratumoral heterogeneity. As in the normal mammary gland, where cellular heterogeneity has been recognized and studied for decades, phenotypic heterogeneity at the cellular level is also common within breast tumors. For example, in the normal mammary gland, only $30-40 \%$ of cells express ER and PR; likewise, in $\mathrm{ER}^{+}$breast tumors, $\mathrm{ER}^{+}$cells express variable levels of ER protein, and up to
99\% of all tumor cells may not express any detectable ER at all (Harvey et al. 1999, Hammond et al. 2011). In a similar fashion, PR is not generally expressed in every cell in $\mathrm{PR}^{+}$ tumors. Although it is not currently useful in clinical decision making, the expression of many other protein markers (e.g., cytokeratin 5, CD44, CD24, PTCH1, and $\mathrm{SMO}$ ) is also known to vary from cell to cell in some breast cancers (Abd El-Rehim et al. 2004, Moraes et al. 2007, Marotta et al. 2011). In addition to simple variability at the protein expression level, there is now known to be genetic heterogeneity within tumors. For instance, single-cell sequencing data demonstrate that there are extensive clonal diversities within a single tumor as a result of the low-frequency point mutations that evolved during tumor development. Noticeably, the mutation frequency is 13 times higher in TNBCs than it is in luminal-type tumors, which suggests an increase in heterogeneity in TNBC (Wang et al. 2014a).

It stands to reason that the observed phenotypic and genetic heterogeneity within a given tumor likely results in functional heterogeneity. Most importantly from a clinical perspective, these heterogeneous tumor cell subpopulations may show different responses to therapy, different division potentials, and varied metastatic properties. Therefore, a better understanding of the mechanisms that contribute to intratumoral heterogeneity in breast tumors, particularly regarding the tumor-initiating subpopulations, is critical for improving current treatment options.

\section{Heterogeneity and the cancer stem cell hypothesis}

The cancer stem cell (CSC) hypothesis was developed in part to explain the intratumoral heterogeneity. According to this hypothesis, many cancers have a unique subset of cells that are referred to as CSCs and have the capacity to self-renew and give rise to other cancer cell types, which creates a hierarchically organized tumor (Visvader \& Lindeman 2012). Furthermore, these CSCs are thought to be the main drivers of tumor growth. Evidence also indicates that CSCs are more resistant to conventional therapies, which suggests that they also play an important role in mediating tumor relapse (Creighton et al. 2009). Therefore, this hypothesis provides a plausible explanation for different types of treatment failure, although the mechanisms of resistance and the proportion of CSCs may vary between different tumors. We and many other groups prefer the term tumorinitiating cells (TICs)' instead of CSCs to distinguish

Published by Bioscientifica Ltd 
these cells from normal stem cells and to emphasize their tumor-initiating capacity.

\section{The identification of TICs in breast tumors}

Putative breast TIC subpopulations can be isolated by fluorescence-activated cell sorting (FACS) using several combinations of cell surface and non-cell surface markers (Table 1), followed by functional assays that demonstrate their enriched tumorigenic potential. For example, subpopulations of human breast tumor cells have been shown by limiting dilution transplantation (LDT) assays to have enriched tumorigenic potential (Al-Hajj et al. 2003, Ginestier et al. 2007). In addition, serial transplantation assays have been performed to demonstrate the selfrenewal capacity of breast TICs, and the heterogeneity of the regenerated daughter tumors has provided evidence of their differentiation capacity (Al-Hajj et al. 2003). Mammosphere formation efficiency (MSFE) assays have also been developed as in vitro surrogates for LDT assays to demonstrate the self-renewal capacity of breast TICs (Dontu et al. 2003). However, MSFE and regenerative cell frequency may not necessarily correlate in all cases, which may limit the interpretation of in vitro assays (Moraes et al. 2007).

To isolate TICs from breast tumors, researchers frequently use fluorescent-conjugated antibodies to cell surface markers, which are specifically expressed or enriched in TIC populations, combined with FACS.
Al-Hajj et al. (2003) published the first markers to enrich for human breast TICs in 2003. The authors used two cell surface markers, the glycoproteins CD44 and CD24, to isolate $\mathrm{CD} 44^{+} / \mathrm{CD} 24^{-/ \mathrm{low}} / \mathrm{Lin}^{-}$cells from primary human/xenograft breast tumors, and they showed that this cell population is more tumorigenic than the other cell populations are, which suggests that it is enriched for TICs. Importantly, this tumor-initiating advantage is maintained during serial passages, and the new generations of tumors contain phenotypically diverse populations (Al-Hajj et al. 2003). Interestingly, CD44 and CD24 markers fail to enrich for TICs in several murine xenograft models that are $\mathrm{ER}^{-}$and triple-negative (Meyer et al. 2010), which suggests that TIC populations may vary between different breast cancer subtypes.

Surrogate markers for $\mathrm{CD} 44^{+} / \mathrm{CD} 24^{-}$cells have also been suggested, including ganglioside GD2 (a glycosphingolipid) and protein $C$ receptor (PROCR) (Shipitsin et al. 2007, Battula et al. 2012). Almost all GD2 ${ }^{+}$cells are $\mathrm{CD} 44^{+} / \mathrm{CD} 24^{-}$, and knockdown of GD3 synthase, an enzyme involved in the synthesis of GD2, in GD2 ${ }^{+}$cells reduces their TIC properties, which suggests that GD2 and CD44 may be phenotypic indications of underlying mechanisms that drive TIC function. PROCR is a cell surface receptor that is specifically expressed in CD $44^{+}$ cells. Unlike CD44, which is also expressed in leukocytes and myofibroblasts, PROCR expression is restricted to CD44 ${ }^{+}$epithelial cells. PROCR was initially identified as

Table 1 Functionally defined TIC markers for human breast tumors and mouse mammary tumors

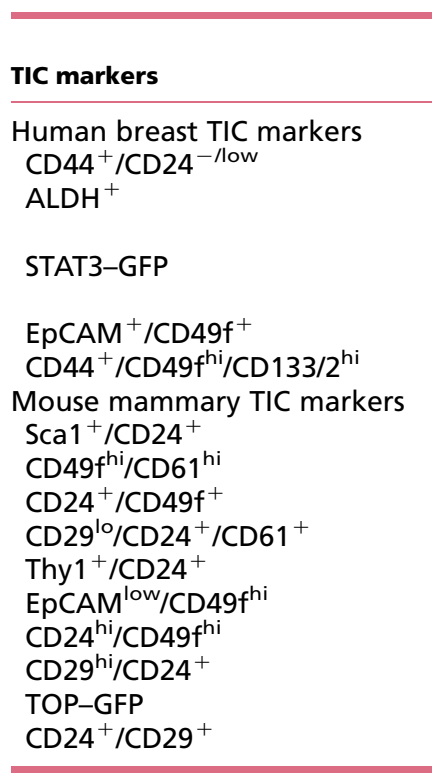

Tumor subtypes
NR
Basal-like
Claudin-low (cell line
$\quad$ xenografts)
Triple-negative
ER

Luminal (MMTV-Neu)
Luminal (MMTV-Neu)
Luminal (MMTV-PyMT)
Basal-like (MMTV-Wnt1)
Basal-like (MMTV-Wnt1)
Basal-like (MMTV-Wnt1)
Basal-like (MMTV-Wnt1)
Basal-like (p53-null)
Basal-like (p53-null)
Basal-like (Brca1-deficient)

\begin{tabular}{|c|c|}
\hline $\begin{array}{l}\text { TIC frequency } \\
\text { before enrichment }\end{array}$ & $\begin{array}{l}\text { TIC frequency } \\
\text { after enrichment }\end{array}$ \\
\hline NR & NR \\
\hline NR & NR \\
\hline NR & NR \\
\hline NR & $1 / 71$ \\
\hline NR & NR \\
\hline NR & $1 / 303$ \\
\hline NR & $1 / 70$ \\
\hline NR & NR \\
\hline NR & $1 / 303$ \\
\hline NR & NR \\
\hline NR & $1 / 79$ \\
\hline $1 / 685$ & $1 / 71$ \\
\hline 1/21 583 & $1 / 302$ \\
\hline NR & $1 / 48-1 / 225$ \\
\hline NR & NR \\
\hline
\end{tabular}

References

Al-Hajj et al. (2003)

Ginestier et al. (2007) and

Liu et al. (2014)

Wei et al. (2014)

Lee et al. (2014)

Meyer et al. (2010)

Liu et al. (2007)

Lo et al. (2012)

Ma et al. (2012)

Vaillant et al. (2008)

Cho et al. (2008)

Feng et al. (2014)

Lee et al. (2014)

Zhang et al. (2008)

Zhang et al. (2010)

Vassilopoulos et al. (2008)

NR, not reported. 
an embryonic stem cell (ESC) marker (Ramalho-Santos et al. 2002), which suggests that it may play a general role in stem cell function.

More recently, integrins have been identified as human breast TIC markers, because they are differentially expressed between breast TICs and non-TICs. For example, the $\alpha 6$ integrin (CD49f) marks TICs in $\mathrm{ER}^{-}$and triplenegative breast tumor xenografts (Meyer et al. 2010, Lee et al. 2014). Using a combination of CD49f, CD44, and CD24 may further enrich for breast TICs from patient breast tumor samples, as compared to CD44 and CD24 alone; MSFE assays show that the self-renewal capacity is predominantly in the $\mathrm{CD} 44^{\text {high }} / \mathrm{CD} 24^{\text {low }} / \mathrm{CD} 49 \mathrm{f}^{+}$population but not in the $\mathrm{CD} 44^{\mathrm{high}} / \mathrm{CD} 24^{\text {low }} / \mathrm{CD} 49 \mathrm{f}^{-}$population (Ghebeh et al. 2013).

A different set of cell surface proteins have been used to enrich for TICs from mouse mammary tumors. In mouse mammary tumor virus (MMTV)-Neu tumors, the stem cell antigen 1 (Sca1) ${ }^{+} / \mathrm{CD} 24^{+}$combination and the $\beta 3$ integrin CD61 combined with CD49f (CD49f $\mathrm{fi}^{\mathrm{hi}} \mathrm{CD} 61^{\mathrm{hi}}$ ) enrich for TICs (Liu et al. 2007, Lo et al. 2012). In MMTVPyMT tumors, the $\mathrm{CD} 24^{+} / \mathrm{CD} 49 \mathrm{f}^{+}$combination enriches for TICs (Ma et al. 2012). In MMTV-Wnt1 tumors, the $\mathrm{CD} 61^{+} / \mathrm{CD} 29^{\mathrm{lo}} / \mathrm{CD} 24^{+}$combination, the thymocyte antigen 1 (Thy1) ${ }^{+} / \mathrm{CD} 24^{+}$combination, the $\mathrm{EpCAM}^{\text {low }} /$ CD $49 \mathrm{f}^{\text {hi }}$ combination, and the $\mathrm{CD} 24^{\text {hi }} / \mathrm{CD} 49 \mathrm{f}^{\text {hi }}$ combination all enrich for TICs (Cho et al. 2008, Vaillant et al. 2008, Feng et al. 2014, Lee et al. 2014). In both p53null and Brca1-deficient tumors, TICs are enriched in the $\beta 1$ integrin $(\mathrm{CD} 29)^{\mathrm{hi}} / \mathrm{CD} 24^{+}$cells (Vassilopoulos et al. 2008, Zhang et al. 2008).

Non-cell surface markers have also been used successfully to enrich for TICs. For example, aldehyde dehydrogenase (ALDH) activity has been used to identify stem cells in mouse mammary glands and human breast tumors (Ginestier et al. 2007). Results showed that $\mathrm{ALDH}^{+}$cells perform better than negative cells do in LDT assays, and they generate tumors that recapitulate the heterogeneity of the parental tumors in terms of enzyme activity. However, a different study found that although many basal/mesenchymal breast cancer cell lines are positive for ALDH activity, the majority of luminal-type breast cancer cell lines are negative (Charafe-Jauffret et al. 2009), which suggests that distinct breast TIC populations may exist in different types of breast tumors. That study also revealed the limited overlap between the $\mathrm{CD} 44^{+} / \mathrm{CD} 24^{-}$and ALDH $1^{+}$populations, which suggests that there may be distinct breast TIC populations even within individual tumors. Therefore, similar to the restricted application of
$\mathrm{CD} 44^{+} / \mathrm{CD} 24^{-/ \text {low }} /$ Lin $^{-}$markers, ALDH activity may only be useful for certain breast tumor subtypes.

Because several cellular signaling pathways are key regulators of breast TIC function, fluorescent reporters of their downstream activity can also serve as functional breast TIC markers. For example, a recent study showed that a Wnt signaling reporter is preferentially activated in TICs in basal-like, p53-null mouse mammary tumors and that cell populations that are isolated based on the expression of the reporter are highly enriched for TICs (Zhang et al. 2010). The utility of this reporter has not been explored fully in models of human breast cancer.

More recently, a lentiviral STAT3-EGFP reporter was shown by both MSFE and limiting-dilution transplantation to be a potent and functionally relevant breast TIC marker in claudin-low cell line xenograft models of human breast cancer (Wei et al. 2014). These fluorescent pathway reporters facilitate the visualization of specific signaling pathway activity in live cells and, more broadly, facilitate stem cell research by enabling direct FACS.

It is worth noting that there are huge variations between TIC frequencies estimated by different TIC markers. For example, breast cancer cell line MDA231 contains $85 \% \mathrm{CD}_{4} 4^{+} / \mathrm{CD} 24^{-}$cells vs $0.88 \%$ ALDE$\mathrm{FLUOR}^{+}$cells, whereas breast cancer cell line SKBR3 contains $0 \% \mathrm{CD} 44^{+} / \mathrm{CD}^{2} 4^{-}$cells vs $95.3 \%$ ALDEFLUOR $^{+}$ cells (Sheridan et al. 2006, Charafe-Jauffret et al. 2009). Table 2 summarizes the percentage of marker-expressing cells in frequently used breast cancer cell lines.

Researchers have tried to consolidate the discrepancy by applying different TIC markers to different molecular subtypes of breast cancers (Ricardo et al. 2011) as well as by arguing that different sets of markers represent TICs in different states of mesenchymal-epithelial transition (MET)/epithelial-mesenchymal transition (EMT) (Liu et al. 2014). Unfortunately, even within the same molecular subtypes and using the same TIC marker set, marker expression does not correlate with TIC frequency estimated by functional assays. For example, the claudin-low-type human breast cancer cell lines SUM159 and MDA231 contain comparable percentages of $\mathrm{CD} 44^{+} / \mathrm{CD} 24^{-}$cells (95\% vs 98\%; Fillmore \& Kuperwasser 2008), yet SUM159 exhibits an MSFE that is much higher than that of MDA231, whereas MDA231 display a much higher tumorigenic capacity than that of SUM159 as judged by LDT assays (Wei et al. 2014). Similarly, although the percentages of $\mathrm{CD}_{4} 4^{+} / \mathrm{CD} 24^{-} / \mathrm{ESA}^{+}$cells in SUM149 and SUM159 correlate well with their MSFEs (Fillmore \& Kuperwasser 2008), they fail to predict the relative tumorigenic capacity of SUM159 and MDA231 cells (Wei et al. 2014).

Published by Bioscientifica Ltd. 
Table 2 Frequency of TIC markers in frequently used breast cancer cell lines

\begin{tabular}{|c|c|c|c|c|c|}
\hline \multirow{2}{*}{$\frac{\text { Cell line }}{\text { BT474 }}$} & \multicolumn{3}{|c|}{ Percentage of CD44 ${ }^{+} / \mathrm{CD} 24^{-}$} & $\begin{array}{c}\text { Percentage of } \\
\text { CD44 }^{+} / \text {ICD24 }^{-} / \text {/ESA }^{+}\end{array}$ & \multirow[t]{2}{*}{ Percentage of ALDH ${ }^{+}$} \\
\hline & 0 & 0 & & & \\
\hline HCC1937 & & 57 & & & 2.26 \\
\hline HS578T & 86 & 64 & & & 0.6 \\
\hline MCF10A & 17 & 3 & 16 & 0.25 & 0.32 \\
\hline MCF12A & & 5 & & & \\
\hline MCF7 & 0 & 0 & 0 & 0 & 0.2 \\
\hline MDA-MB-231 & 85 & 76 & 98 & 1.8 & 0.88 \\
\hline MDA-MB-436 & 72 & & & & 2.65 \\
\hline MDA-MB-453 & & 0 & & & 3.54 \\
\hline MDA-MB-468 & 3 & 0 & & & \\
\hline SKBR3 & 0 & 0 & & & 95.3 \\
\hline SUM1315 & 97 & & 92 & 2.4 & \\
\hline SUM149 & & & 5 & 2.3 & 5.96 \\
\hline SUM159 & & 55 & 95 & 1.7 & 5.49 \\
\hline SUM225 & & & 1 & 0.6 & 2.12 \\
\hline T47D & 0 & 0 & & & 0 \\
\hline ZR75.1 & 0 & 0 & & & 1.02 \\
\hline References & $\begin{array}{l}\text { Sheridan } \\
\text { et al. (2006) }\end{array}$ & $\begin{array}{l}\text { Marotta } \\
\text { et al. }(2011)^{a}\end{array}$ & $\begin{array}{c}\text { Fillmore \& } \\
\text { Kuperwasser }(2008)^{a}\end{array}$ & $\begin{array}{c}\text { Fillmore \& } \\
\text { Kuperwasser }(2008)^{a}\end{array}$ & $\begin{array}{c}\text { Charafe-Jauffret } \\
\text { et al. (2009) }\end{array}$ \\
\hline
\end{tabular}

apercentage estimated from bar graph.

Furthermore, the lack of a correlation between MSFEs and tumorigenic capacity has been widely observed. For example, LDT assay has shown that the breast cancer cell line SUM149 has a higher MSFE after normalization to proliferation but a lower tumor-formation frequency as compared to SUM159 (Fillmore \& Kuperwasser 2008). A similar but more dramatic result has been observed between SUM159 and MDA231 xenograft cells (Wei et al. 2014). One recent study also showed that a marker that bears cells in different cell lines responds to therapies inconsistently, which highlights a lack of correlation between TIC markers and treatment responses (Liu et al. 2014).

To date, none of the identified breast TIC markers has been shown to be universal. Thus, continuing to search for novel markers and using novel combinations of current markers will presumably improve TIC identification and isolation and may lead to a better understanding of breast TICs. Because of the inconsistent interpretation of TIC markers within and across breast cancer samples, it is important to rigorously evaluate TIC frequency by LDT assays whenever possible rather than simply relying on TIC markers.

\section{Breast TICs may be resistant to conventional systemic therapies}

The content of TICs in breast tumors has been shown to be closely related to clinical outcome. For example, most triple-negative tumors belong to either a basal-like or a claudin-low subtype (Herschkowitz et al. 2012).
Claudin-low tumors have worse prognoses as compared to luminal A tumors as well as clear enrichment for TIC-associated signatures (Prat et al. 2010, Herschkowitz et al. 2012). The aggressiveness of primary breast cancers has also been associated with TIC frequency: poorly differentiated tumors display a higher content of TICs in xenotransplantation experiments (Pece et al. 2010, Usary et al. 2013). Consistent with these findings, accumulating evidence has revealed that breast TICs are resistant to diverse types of breast cancer therapies.

\section{Resistance to chemotherapy}

Eventual relapse following chemotherapy has been a major challenge in treating breast cancer (1998). The existence of de novo chemoresistant breast TICs could be a major cause of disease relapse. There are two essential pieces of evidence that support this idea: i) chemotherapy treatment enriches for cells that express markers of breast cancer TICs. ii) Tumors enriched in markers of breast TICs are comparatively resistant to chemotherapy treatment. For the former piece of evidence, it has been shown that, following chemotherapy, residual breast cancers and cancer cell lines have increased $\mathrm{CD} 44^{\mathrm{high}} / \mathrm{CD} 24^{\text {low }}$ subpopulations, increased MSFE and tumor-initiating efficiency, and enriched expression of TIC signature genes (Yu et al. 2007, Fillmore \& Kuperwasser 2008, Li et al. 2008, Creighton et al. 2009). For the latter, it has been shown that breast tumors that have been classified as claudin-low,

Published by Bioscientifica Ltd. 
a molecular subtype that is enriched for TIC features, are relatively resistant to chemotherapy (Usary et al. 2013).

The hypothesized quiescent nature of breast TICs may confer their chemoresistance, because efficient induction of apoptosis by chemo-drugs usually requires cell division (Naumov et al. 2003, Moore \& Lyle 2011). There are several lines of evidence showing that breast TICs are slow cycling: i) markers from the gene expression signature that is derived from quiescent normal human mammary stem cells can be used to isolate breast TICs, which suggests that breast TICs are correspondingly quiescent (Pece et al. 2010). ii) The dye retention side population (SP) is enriched for TICs in breast cancer cell lines, and it shows increased expression of negative cell cycle regulators (Goodell et al. 1996, Hirschmann-Jax et al. 2004, Patrawala et al. 2005, Zhou et al. 2007). iii) $\mathrm{CD} 44^{+} / \mathrm{CD} 24^{-/ \text {low }}$ cells that have been isolated from a panel of breast cancer cell lines are slow cycling and resistant to chemotherapies (Fillmore \& Kuperwasser 2008). Hence, although it may not be true in all tumors, the slow-cycling nature of breast TICs may serve as a potential mechanism for chemoresistance (Moore \& Lyle 2011).

Another potential mechanism that may confer chemoresistance to breast TICs is the increased presence of ATP binding cassette $(\mathrm{ABC})$ transporters, which actively pump drugs out of cells, relative to the bulk of the tumor. The breast cancer resistance protein (BCRP) was first identified in a multidrug resistant (MDR) subline of MCF7, and it is involved in in vitro MDR (Doyle et al. 1998). Likewise, the increased expression of the P-glycoprotein (Pgp), another well-characterized $\mathrm{ABC}$ transporter, is associated with doxorubicin resistance in multiple breast cancer cell lines (Turton et al. 2001). In patient breast tumor samples, high BCRP expression is correlated with high HER2 expression, lymph node metastasis, and an advanced stage of breast cancer (Xiang et al. 2011). Pgp shows higher expression after treatment with chemotherapy, which suggests that tumor cells that express Pgp may resist to chemotherapy (Rudas et al. 2003). Furthermore, there is evidence to suggest that BCRP and Pgp are preferentially expressed in breast TICs. For example, the SP cells of MCF7 cells, which is enriched for TICs, expresses higher levels of ABC transporters than non-SP cells do (Zhou et al. 2007). On the other hand, in the MDA-MB- 435 cell line, cells that express BCRP are fast cycling and are not enriched in breast TICs as compared to $\mathrm{BCRP}^{-}$cells (Patrawala et al. 2005). These data suggest that different mechanisms may play roles to mediate TIC chemoresistance in different models and that there may be a trade-off between slow cycling and drug efflux properties in conferring drug resistance.

\section{Resistance to radiotherapy}

Malignant cells are usually rapidly dividing, and their DNA damage repair systems frequently fail to perform dependably (Nie 2012). Therefore, malignant cell growth can be effectively controlled by radiotherapy. More than $50 \%$ of breast cancer patients receive radiotherapy during the treatment of their disease (Langlands et al. 2013). Unfortunately, distant metastasis and local recurrence still occur because of treatment resistance (Langlands et al. 2013), especially in patients with basal-like TNBC (Nguyen et al. 2008).

Accumulating evidence suggests that breast TICs are radioresistant (Phillips et al. 2006, Woodward et al. 2007, Prat et al. 2010, Morrison et al. 2011). For example, when they are isolated from $p 53$-null mouse mammary tumors carried by irradiated mice, the $\mathrm{CD} 24^{+} / \mathrm{CD} 29^{+}$subpopulations, which are cell types enriched for TICs, resolve their $\gamma \mathrm{H} 2 \mathrm{Ax}$ DNA damage foci more rapidly than non-TIC subpopulations do; this suggests that mouse mammary TICs have a more effective DNA repair system compared to non-TICs from the same tumor (Zhang et al. 2010). Furthermore, in the human breast cancer cell line MCF7, radiation enriches for breast TIC subpopulations (Phillips et al. 2006, Woodward et al. 2007). Similarly, in two patient-derived TNBC xenograft models (MC1 and BCM-2665A), radiation has been shown to enrich for the $\mathrm{ALDH}^{+}$subpopulation (Atkinson et al. 2010). In addition, clinical data have shown that triple-negative breast tumors, which include the breast TIC-enriched claudinlow subtype, are generally more resistant to radiotherapy as compared to other types of tumors (Prat et al. 2010). Together, these data suggest that breast TICs are more resistant to radiotherapy. However, the resistance of breast TICs to radiation is not without controversy. One study showed a depletion of TICs in one patient-derived xenograft after radiation, as measured by the percentage of $\mathrm{CD} 44^{+} / \mathrm{CD} 24^{- \text {low }} / \mathrm{Lin}^{-}$cells, ALDH1 levels, and MSFE, but the opposite was observed in a second independent PDX model (Zielske et al. 2011). This controversy may be the result of the use of inappropriate breast TIC markers, or it may indicate that some breast tumors have a radiosensitive TIC population.

\section{Resistance to endocrine therapy}

Endocrine therapy drugs, such as tamoxifen and aromatase inhibitors, have been the cornerstone of treating $\mathrm{ER}^{+}$breast cancer and have significantly decreased mortality (Jensen \& Jordan 2003, Johnston \& Dowsett 2003,

Published by Bioscientifica Ltd 
Dowsett et al. 2005). However, disease recurrence occurs in up to $25-30 \%$ of the patients within 5 years following tamoxifen treatment (Early Breast Cancer Trialists' Collaborative Group (EBCTCG) 2005, Howell \& Wardley 2005). For patients with recurrence, de novo and acquired resistance have become major challenges for successful treatment (Early Breast Cancer Trialists' Collaborative Group (EBCTCG) 2005). A range of mechanisms have been postulated to account for tamoxifen resistance, from a lack of ER $\alpha$ expression (Clarke et al. 2003) to an increased expression of growth factor tyrosine kinases (Knowlden et al. 2003, Dowsett et al. 2006, Massarweh et al. 2006, Giltnane et al. 2007).

The role of breast TICs in endocrine therapy resistance is controversial. On the one hand, even in $\mathrm{ER}^{+}$tumors, breast TICs are predicted to be $\mathrm{ER}^{-}$, because $\mathrm{CD} 44^{+}$cells are $\mathrm{ER}^{-}$and the expression of ALDH1 is inversely correlated with ER and PR expression (Clarke et al. 1997, Ginestier et al. 2007, Shipitsin et al. 2007, Harrison et al. 2013), which suggests that breast TICs themselves would not respond to endocrine therapy directly. On the other hand, estrogen has been shown to expand the $\mathrm{ER}^{-}$breast TIC population via paracrine FGF/Tbx3 or EGFR/Notch signaling (Fillmore et al. 2010, Harrison et al. 2013), which suggests that they could be indirectly sensitive to endocrine therapy. However, a recent study provided evidence to support the predicted resistance of $\mathrm{ER}^{-}$cells to endocrine therapy by showing the expansion of the $\mathrm{ER}^{-} / \mathrm{PR}^{-}$subpopulation in $\mathrm{ER}^{+} / \mathrm{PR}^{+}$breast cancers in response to antiestrogen treatment (Haughian et al. 2012). This result suggests that $\mathrm{ER}^{-}$breast TICs are likely to be resistant to endocrine therapy.

\section{Resistance to anti-HER2 therapy}

About $15-20 \%$ of breast cancer patients have breast tumors of the HER2 ${ }^{+}$subtype, which means that the tumor cells have overexpression typically accompanied by HER2 gene amplification (Slamon et al. 1987, Allred 2010). HER2-targeting drugs, such as trastuzumab, greatly improve the prognosis of patients with HER $2^{+}$breast cancer. However, $50 \%$ of recurrences are the result of $d e$ novo resistance and, of the patients with HER2 ${ }^{+}$metastatic tumors that do respond to trastuzumab initially, the majority acquire resistance within 1-2 years of treatment (Lan et al. 2005, Chung et al. 2013).

Although anti-HER2 agents have been shown to target breast TICs with, or sometimes without, HER2 amplification (Korkaya et al. 2009, Magnifico et al. 2009, Ithimakin et al. 2013), several lines of evidence support a role for breast TICs in trastuzumab resistance: i) HER2 overexpression expands the breast TIC population in vitro and in vivo (Korkaya et al. 2008, Cicalese et al. 2009). ii) Signaling pathways that are known to generate trastuzumab resistance also expand the breast TIC population (Korkaya et al. 2012, Chakrabarty et al. 2013, Hanker et al. 2013, Ding et al. 2014). iii) Long-term trastuzumab treatment of resistant cells enriches the breast TIC population as measured by TIC markers (Reim et al. 2009, Korkaya et al. 2012). Taken together, these results suggest that combining breast TIC-targeting agents with HER2-targeting agents will benefit patients that do not respond to anti-HER2 therapies alone.

\section{Plasticity of breast TICs and potential therapeutic implications}

There is evidence to suggest that breast TICs and non-TICs are interconvertible, either spontaneously or through induction (Meyer et al. 2009, Gupta et al. 2011, Iliopoulos et al. 2011, Kim et al. 2013). The apparent plasticity of breast TICs has also been hypothesized to be an obstacle in treating breast cancer. Although facilitating the transformation of breast TICs to breast non-TICs can be an effective therapeutic strategy, the opposite transformation would obviously be problematic (Visvader \& Lindeman 2012). Indeed, it has been reported in breast cancer cell lines that a subset of cells in certain phenotypic states will eventually return to proportions of phenotypic equilibrium by stochastically transitioning between states following the Markov model, which also predicts that breast TICs and non-TICs are capable of converting to each other (Gupta et al. 2011). In support of this model, it has been shown that in multiple breast cancer cell lines, a single $\mathrm{CD} 44^{+} / \mathrm{CD} 24^{+}$cell gives rise to the $\mathrm{CD} 44^{+} / \mathrm{CD} 24^{-}$ progeny in vitro and that xenograft tumors generated by $\mathrm{CD} 44^{+} / \mathrm{CD} 24^{+}$cells are similar to tumors initiated by $\mathrm{CD} 44^{+} / \mathrm{CD} 24^{-}$cells (Meyer et al. 2009). Likewise, another study showed that in transformed MCF10A cells, the $\mathrm{CD} 44^{+} / \mathrm{CD} 24^{-/ \text {low }}$ stem-like subpopulation is able to rapidly convert back to other cell types until it reaches an equilibrium proportion in which $10 \%$ of its cells are similar to those of the parental cell line and that the nonTICs can give rise to breast TICs in vivo, which demonstrates that interconversion between these cell states is possible (Iliopoulos et al. 2011). Furthermore, in transformed human mammary epithelial (HMLER) cells, CD44 ${ }^{\text {low }}$ cells convert spontaneously into $\mathrm{CD} 44^{+}$cells in vitro and in vivo (Chaffer et al. 2011), which demonstrates another case of breast TIC plasticity.

Published by Bioscientifica Ltd. 
The underlying mechanism of such conversions also emerged recently, and it was found to be associated with the EMT program. For instance, knocking down of FOXC2 leads to inhibition of mesenchymal phenotype and reduction in tumor-initiating capacity in breast cancer cell lines (Hollier et al. 2013). Furthermore, it has been shown that the ZEB1 promoter undergoes conformational changes in response to the TGF $\beta$ signal to drive breast cancer cell plasticity (Chaffer et al. 2013). Similarly, the conversion of the luminal-like $\mathrm{CD} 44^{+} / \mathrm{CD} 24^{+}$cells into basal-/mesenchymal-like CD $44^{+} / \mathrm{CD} 24^{-}$cells depends on the Activin/Nodal-initiated TGF $\beta$ signaling (Meyer et al. 2009). These studies have been performed predominantly in cell line models, and the degree to which plasticity occurs in vivo in PDX models has not been established.

This 'plastic CSC' phenomenon may add additional layers of complexity to the treatment of breast cancer. In particular, if TICs can be generated de novo from non-TICs within a tumor, therapies designed to target TICs may ultimately fail. In that case, targeting both TICs and nonTICs is imperative. Targeting the de-differentiation mechanism, which could result from gene mutations, epigenetic modifications, or stochastic events, is also promising (Marjanovic et al. 2013).

\section{Metastatic potential of breast TICs and therapeutic implications}

The proposed enhanced metastatic potential of breast TICs may be another treatment hurdle. Because TICs have the ability to generate tumors at orthotropic sites, it has been hypothesized that they could also generate tumors at metastasis sites (Brabletz et al. 2005). For example, it has been shown that spontaneous lung metastases and primary breast tumors share similar CD $44^{+}$profiles that are enriched for breast TICs (Liu et al. 2010), which suggests that TICs are involved in spontaneous metastasis. Furthermore, $\mathrm{ER}^{-}$metastatic tumors have been found in $\mathrm{ER}^{+}$patients, which demonstrates the metastasis potential of $\mathrm{ER}^{-}$TICs (Lower et al. 2005, Fehm et al. 2008). The EMT program is thought to enable the invasion of tumor cells into the stroma, and it therefore may initiate the early steps of the metastatic process (Scheel \& Weinberg 2012).

Importantly, the EMT program has been coupled with breast TIC formation. For instance, human mammary epithelial cells (MECs) undergoing EMT also show enhanced TIC properties (Mani et al. 2008), and the expression of EMT regulators forces non-TICs into the TIC state (Li et al. 2009, Chaffer et al. 2013, Hollier et al.
2013). Moreover, following chemotherapy, residual breast cancer cells display EMT features (Creighton et al. 2009), and knockdown of TWIST reverses chemotherapy-induced MDR and EMT concurrently (Li et al. 2009), which indicates the formation of drug-resistant breast TICs during EMT. Additionally, MET, a reverse process of EMT, is thought to be essential during the last step of metastasis (Scheel \& Weinberg 2012). Contrary to the established pro-EMT signaling, which involves TGF $\beta$ and TWIST, TGF $\beta$ and Id1 signaling has been reported to induce the MET and stemlike phenotypes in breast cancer cells by targeting TWIST (Stankic et al. 2013). Together, these data link breast TIC formation to both EMT and MET programs, and they suggest the metastatic potential of TICs.

Breast TICs were also thought to possess enhanced metastasis capacity. For example, $\mathrm{CD} 44^{+} / \mathrm{CD} 24^{-}$human breast cancer stem-like cells not only express EMT markers (Mani et al. 2008), but they also display an increased incidence and burden of metastasis when they are administrated through tail veil injection (Croker et al. 2009). In addition, ALDH expression is associated with the MET state, and ALDH activity is largely a result of the ALDH1A3 isoform that is associated with metastasis (Marcato et al. 2011, Liu et al. 2014). The metastatic potential of TICs provides insight into the mechanism of cancer progression. Targeting TICs may therefore help eradicate primary tumors and prevent metastasis simultaneously. However, because of the complicated involvement of some common programs in both the MET and the EMT processes, considerable caution is required when attempting to pinpoint the different progression stages in each patient.

\section{Pathways that regulate breast TICs and confer resistance}

TICs may survive conventional therapy and contribute to recurrence and metastasis later, even in a rapidly shrinking tumor. Therefore, a combination of drugs that target TICs and non-TICs and a combination of parameters that measure tumor volume and TIC functions are likely required for future clinical studies. In order to develop TIC-targeting drugs, the signaling pathways that are utilized by breast TICs and therapeutic agents that target those pathways are currently being intensively studied.

\section{Hedgehog signaling}

Hedgehog (HH) was first identified in a genetic screen for the genes required for Drosophila embryonic patterning

Published by Bioscientifica Ltd 
(Driever \& Nusslein-Volhard 1988). In mammals, HH signaling functions in multiple tissue/cell types in the developing embryo to direct organogenesis, including the ventral-dorsal pattern formation in the neural tube and the anterior-posterior pattern formation in the limb (Ingham \& McMahon 2001). Despite the debate about its functional significance in postnatal mammary gland development (Lewis \& Visbal 2006), paracrine $\mathrm{HH}$ signaling has been shown to stimulate proliferation and to expand the progenitor population in the mouse mammary gland in transgenic mice (Visbal et al. 2011, Garcia-Zaragoza et al. 2012). Furthermore, activation of HH signaling promotes mammosphere formation of normal mammary stem cells, whereas inhibition of $\mathrm{HH}$ signaling by cyclopamine exerts the opposite effects, which suggests that $\mathrm{HH}$ signaling plays a role in normal mammary stem cells (Liu et al. 2006, Moraes et al. 2007). Importantly, HH signaling is activated in the $\mathrm{Lin}^{-} / \mathrm{CD} 44^{+} / \mathrm{CD} 24^{-/ \text {low }}$ human breast TIC subpopulation, and it promotes mammosphere formation in the p53-null mouse mammary tumor model through Bmi-1, a polycomb protein that is overexpressed in the $\mathrm{Lin}^{-} / \mathrm{CD} 29^{\mathrm{H}} / \mathrm{CD} 24^{\mathrm{H}}$ subpopulation. (Liu et al. 2006, Zhang et al. 2008). More recently, it was reported that GLI1, a downstream mediator of $\mathrm{HH}$ signaling, stimulates tumor initiation in triple-negative breast tumors (Goel et al. 2013), and GLI1 is required for breast TIC self-renewal in $\mathrm{ER}^{+}$breast cancer cells (Sun et al. 2014). These findings imply that $\mathrm{HH}$ signaling components could be targets for treating breast TICs.

\section{WNT signaling}

Wnt1 was originally identified as a proto-oncogene because it was retrieved from an oncogenic integration site of MMTV (Nusse \& Varmus 1982), and Wnt1 transgenic overexpression generates mammary tumors in mice within 6 months (Tsukamoto et al. 1988). Wnt signaling is required for normal mammary stem cell function and Wnt-responsive cells show enriched stem cell activity in the mammary gland (Andl et al. 2002, van Amerongen et al. 2012). Therefore, Wnt1-induced tumor formation may be a result of the ability of Wnt signaling to transform mammary stem cells (Li et al. 2003, Zeng \& Nusse 2010). Wnt-responsive cells are also enriched in TICs in mouse mammary tumors (Zhang et al. 2010), which are located close to distorted blood vessels (Zhu et al. 2013, Vadakkan et al. 2014); this suggests that WNT signaling plays a role in breast TICs. Accordingly, a WNT inhibitor decreases the TIC frequency of an RAS-transformed mesenchymal subpopulation of human MECs
(Scheel et al. 2011). Importantly, WNT signaling plays a pivotal role in the radioresistance of breast TICs. For example, TICs isolated from p53-null mouse mammary tumors have enriched Wnt signaling activity and more effective DNA damage repair systems (Zhang et al. 2010). In addition, clinically relevant doses of radiation specifically enrich the SP and the Sca1 ${ }^{+}$stem-like subpopulations in MECs that have activated Wnt signaling but not in WT MECs (Woodward et al. 2007). Finally, radiation enriches for $\mathrm{Sca}^{+}$cells, and these cells show elevated Wnt signaling activity and fewer $\gamma \mathrm{H} 2 \mathrm{Ax}$ DNA damage foci as compared to Sca $1^{-}$cells (Chen et al. 2007). Together, these findings suggest that WNT signaling inhibitors have the potential to sensitize resistant breast TICs to radiotherapy. Recent studies by Gunther et al. reported that both the luminal and basal populations were required for efficient tumor formation in the MMTV-driven Wnt1 genetically engineered mouse model and were dependent on luminal Wnt1 expression (Cleary et al. 2014).

$\mathrm{WNT} / \beta$-catenin signaling is activated by the binding of a WNT ligand to its receptor, Frizzled, and its co-receptor, lipoprotein receptor-related protein 5/6 (LRP5/6), which makes Frizzled and LRP5/ 6 candidate targets for inhibiting WNT signaling (MacDonald et al. 2009). Salinomycin inhibits WNT/ $\beta$-catenin signaling by inducing LRP6 degradation, and it has also been identified as a selective inhibitor of breast TICs in a high throughput screen (Gupta et al. 2009, Lu et al. 2011, Lu \& Li 2014). A number of natural dietary components, including curcumin, piperine, and sulforaphane, have also been found to inhibit breast TICs and to down-regulate the WNT pathway (Kakarala et al. 2010, Park et al. 2010). Despite this progress, the development of potent WNT inhibitors remains challenging (Anastas \& Moon 2013). Interestingly, pSTAT3 binds to the promoter region of $\beta$-catenin directly and activates $\beta$-catenin transcription in MCF7 and BT474 breast cancer cell lines, and pSTAT3 and $\beta$-catenin staining are significantly correlated in primary breast tumors (Armanious et al. 2010). Investigating the crosstalk between STAT3 and WNT signaling may potentially provide novel intervention targets for inhibiting WNT signaling.

\section{NOTCH signaling}

In vertebrates, there are four transmembrane Notch receptor proteins: Notch1-4. Notch4 is a proto-oncogene that is capable of inducing mouse mammary tumors when it is abnormally expressed by MMTV insertion (Gallahan \& Callahan 1987, 1997). Notch pathway activators promote,

Published by Bioscientifica Ltd 
whereas Notch pathway inhibitors suppress, the formation of secondary mammospheres from normal mammary stem cells, which suggests that Notch signaling plays an important role in normal stem/progenitor cell function (Dontu et al. 2004). Moreover, both NOTCH1 and NOTCH4 antibodies decrease the MSFE of breast tumor cells derived from PDX or patient samples, which suggests their function in breast TICs (Farnie et al. 2007, Qiu et al. 2013). Importantly, NOTCH4 signaling activity is eightfold higher in the $\mathrm{ESA}^{+} / \mathrm{CD} 44^{+} / \mathrm{CD} 24^{\text {low }}$ TIC subpopulation, and NOTCH4 inhibition reduces the TIC frequency in human breast cancer cell lines in vivo (Harrison et al. 2010). More recently, it was found that in basal-like breast cancer, NF- $\mathrm{kB}$ induces the expression of JAG1, a Notch ligand, in non-TICs, and this stimulates NOTCH signaling in TICs in trans, which leads to breast TIC expansion (Yamamoto et al. 2013). Another study showed that $\mathrm{NOTCH}$ signaling is activated in $\mathrm{ER}^{-}$cells, whereas it is inhibited in $\mathrm{ER}^{+}$cells by estradiol, which makes NOTCH signaling a potential target for overcoming endocrine therapy resistance in $\mathrm{ER}^{-}$cells, the putative breast TIC population (Rizzo et al. 2008).

NOTCH signaling is activated by $\gamma$-secretase cleavage of its intracellular domain. Therefore, $\gamma$-secretase inhibitors (GSIs) have been used as pan-NOTCH signaling inhibitors (Bray 2006). For example, the GSI MRK-003 was shown to successfully eliminate TICs in a mouse model of ErbB2 breast cancer, as measured by LDT assays (Kondratyev et al. 2012). More recent and promising data suggest that the MRK-003 reduces breast TICs in patientderived xenograft tumors and that MK-0752, an MRK-003 analog, may reduce breast TICs in patient biopsies in a phase I clinical trial, as measured by MSFE and the expression levels of stem cell markers (Schott et al. 2013). However, it has also been shown that NOTCH4 knockdown is more efficient than GSIs are in targeting TICs; this is likely because NOTCH4 activity is increased and NOTCH1 activity is decreased in breast TICs (Harrison et al. 2010). Interestingly, a recent study showed that in some TNBC lines, the activated NOTCH1-ICD is only increased in the $\mathrm{CD} 44^{+} / \mathrm{CD} 24^{\text {low }}$ breast TICs, but not in the $\mathrm{CD} 44^{+} / \mathrm{CD} 24^{-}$breast TICs. Therefore, the $\mathrm{CD} 44^{+} / \mathrm{CD} 24^{\text {low }}$ stem-like population is sensitive to GSIs, but the $\mathrm{CD} 44^{+} / \mathrm{CD} 24^{-}$subpopulation, which is also stemlike, is resistant (Azzam et al. 2013). These data suggest the heterogeneous nature of NOTCH signaling within breast TICs and indicate that, similar to other proposed breast cancer therapies, GSIs may need to be combined with other treatments to maximize their efficiency.

\section{Interleukin 6/STAT3 signaling}

STAT3 belongs to a family of latent transcription factors (Chatterjee-Kishore et al. 2000), and it plays a pivotal role in early embryogenesis by acting to keep ESCs in an undifferentiated state (Matsuda et al. 1999, Raz et al. 1999, Torres \& Watt 2008). Recent evidence suggests that it also plays a role in regulating stem cells in solid tumors, including breast tumors. For example, in breast cancer models, treatment with the STAT3 pathway agonist interleukin 6 (IL6) expands the CD $44^{\text {high }} / \mathrm{CD} 24^{\text {low }}$ stemlike subpopulation (Iliopoulos et al. 2011), whereas shRNA-mediated STAT3 knockdown decreases the TIC frequency (Zhou et al. 2007). Additionally, in patient breast tumor samples, the majority of CD $44^{\text {high }} / \mathrm{CD} 24^{\text {low }}$ cells have been shown to be positive for PSTAT3 staining (Marotta et al. 2011). A more recent report linked high STAT3 activity to high autophagy function, which contributes to chemoresistance in breast cancers (Maycotte et al. 2014). Taken together, these data suggest that STAT3 is associated with breast TIC function.

Recently, our laboratory showed that STAT3 signaling is activated preferentially in TICs of claudin-low-type human breast cancer, which further suggests that STAT3 signaling regulates breast TIC function (Wei et al. 2014). Consistent with these data, a recent study showed that the anti-malarial drug chloroquine inhibits Jak2/STAT3 signaling, decreases the MSFE in a number of TNBC cell lines, and decreases the TIC frequency in MDA231 xenograft tumors (Choi et al. 2014). Importantly, it has also been shown that breast TIC-derived IL6 recruits mesenchymal stem cells, which communicate with breast TICs by secreting additional cytokines and chemokines, thereby creating a breast TIC-promoting microenvironment (Liu et al. 2011). Furthermore, an inflammatory feedback loop has been shown to enhance breast TIC function; in this feedback loop, breast cancer cells under long-term trastuzumab treatment are highly enriched in the $\mathrm{CD} 44^{+} / \mathrm{CD} 24^{-}$ population and secrete high levels of IL6, which in turn acts through the IL6 receptor to expand the $\mathrm{CD} 44^{+} / \mathrm{CD} 24^{-}$ stem-like population (Korkaya et al. 2012).

STAT3 signaling is typically induced by the binding of IL6-type cytokines to gp130 receptors, and this binding activates JAKs ( $\mathrm{Yu} \&$ Jove 2004). Therefore, STAT3 signaling can be inhibited by JAK inhibitors and small molecules that directly target STAT3. The former is exemplified by ruxolitinib, which is currently being tested in phase II trials to treat breast cancer (Quintas-Cardama \& Verstovsek 2013). The latter is exemplified by piperlongumine, which has been shown to block the mammosphere

Published by Bioscientifica Ltd 
formation of patient-derived xenograft tumor cells and to inhibit breast tumor growth in vivo (Bharadwaj et al. 2014). Other in vivo studies have used STAT3 inhibitors, including Cmp188, a competitive small-molecule inhibitor, to compete with STAT3 to bind pY peptides (Xu et al. 2009). In addition, chloroquine, an anti-malarial drug, has been reported to inhibit JAK/STAT3 signaling and to reduce the $\mathrm{CD} 44^{+} / \mathrm{CD} 24^{-/ \text {low }}$ subpopulation in triple-negative breast tumors (Choi et al. 2014).

Another method for inhibiting STAT3 signaling includes blocking the IL6 receptor. For example, a combined treatment using an anti-IL6 receptor antibody and trastuzumab reduces the TIC frequency in trastuzumab-resistant HER2 ${ }^{+}$breast cancer cells (Korkaya et al. 2012). Together, these data suggest that STAT3 inhibitors would be promising therapeutic drug candidates for targeting both breast TICs and their niches.

\section{IL8/CXCR1/2 signaling}

CXCR1 is a member of the G protein-coupled receptor family, and it is highly expressed in $\mathrm{ALDH}^{+}$cells in a number of breast cancer cell lines (Charafe-Jauffret et al. 2009). Treatment with the CXCR ligand IL8 increases the ALDEFLUOR ${ }^{+}$populations and the MSFE in breast cancer cell lines (Charafe-Jauffret et al. 2009, Singh et al. 2013), whereas treatment with a CXCR1 inhibitor depletes the breast TIC subpopulation (Ginestier et al. 2010). IL8 is also secreted by mesenchymal stem cells in response to signals from breast TICs, and it reinforces breast TIC function (Liu et al. 2011). More recently, it was reported that IL8/CXCR1/2-induced mammosphere formation is mediated partially by EGFR/HER2 signaling (Singh et al. 2013), which provides a rationale for using a combined therapeutic strategy. Indeed, the small molecule CXCR1 inhibitor repertaxin has been shown not only to effectively target breast TICs but also to enhance the efficacy of lapatinib in treating $\mathrm{HER}^{+}$breast cancers (Singh et al. 2013).

IL8 is the best-studied CXCR $1 / 2$ ligand, and antibodies against IL8 are currently being tested in clinical trials for the treatment of inflammatory diseases (Skov et al. 2008). However, the benefits of inhibiting IL8 may be limited, because a broad range of other ligands can also stimulate CXCR1/2 (Bieche et al. 2007). Therefore, blocking CXCR1/2 function provides much more specificity. For instance, repertaxin shows potent inhibition of breast TICs in vitro, and it reduces tumor growth and metastasis in vivo (Ginestier et al. 2010). It also has an additive effect when used in combination with lapatinib to treat $\mathrm{HER}^{+}$breast cancers (Singh et al. 2013), and it has undergone clinical testing in combination with chemotherapy to treat patients with HER2 ${ }^{-}$metastatic breast cancer (Schott et al. 2012).

\section{TGF $\beta$ signaling}

TGF $\beta$ family members are multifunctional peptides that regulate cell growth and differentiation (Heldin et al. 1997). TGF $\beta$ signaling has also been shown to maintain the undifferentiated state of human ESCs (James et al. 2005). The role of TGF $\beta$ signaling in mammary carcinogenesis is controversial, because it is known to impair tumorigenesis, but it also triggers the EMT/MET program to facilitate metastasis (Siegel et al. 2003, Muraoka-Cook et al. 2005, Tang et al. 2007, Stankic et al. 2013). Importantly, TGF $\beta$ and its receptor are specifically expressed in $\mathrm{CD}_{4} 4^{+}$cancer cells, and their expression results in a more mesenchymal appearance of those cells (Shipitsin et al. 2007). Together, these data link TGF $\beta$ signaling to a mesenchymal/stem-like state of breast cancer cells. Surprisingly, a recent finding suggested that TGF $\beta /$ Id1 signaling also induces MET and stem-like phenotypes in breast cancer cells, and this only occurs in cells that have already undergone an EMT. Hence, TGF $\beta$ is predicted to facilitate metastasis during both the EMT and MET steps in a sequential manner (Stankic et al. 2013). More recently, an oscillating TGFßR3-JUND signaling circuit was uncovered in basal-like breast cancer cells, which suggests that this is an additional underlying mechanism for intratumoral heterogeneity (Wang et al. 2014b). All of these findings highlight a context-dependent role of TGF $\beta$ in breast TIC plasticity and metastasis.

Several examples illustrate the importance of TGF $\beta$ signaling in chemotherapy-induced breast TIC enrichment and metastasis. In the 4T1 mouse mammary tumor model, the chemotherapy drug doxorubicin induces EMT and promotes a stem-like phenotype by activating TGF $\beta$ signaling, which is effectively blocked by a TGF $\beta$ type 1 receptor kinase inhibitor (TRRI-KI). Combining doxorubicin with TBRI-KI significantly reduces tumor growth and lung metastasis in vivo (Bandyopadhyay et al. 2010). Similarly, the chemotherapy drug paclitaxel enriched for breast TICs in TNBCs, as indicated by MSFE assay and TIC markers (Bhola et al. 2013), and this effect can be prevented by treating with LY2157299, a small molecule T $\beta R I-K I$ (Bhola et al. 2013). However, considering the multiple functions of TGF $\beta$ in the plasticity and metastasis of breast TICs (Stankic et al. 2013, Wang et al. 2014b), additional caution is required when targeting this signaling pathway.

Published by Bioscientifica Ltd. 


\section{Integrin signaling}

Integrins are environmental sensors and, importantly, are differentially expressed between breast TICs and non-TICs. For example, the $\beta 3$ subunit integrin $\mathrm{CD} 61$ has been used to enrich a breast TIC subpopulation in MMTVWht 1 mouse mammary tumors, because the CD29lo/ $\mathrm{CD} 24^{+} / \mathrm{CD} 61^{+}$subset shows increased TIC frequency than the $\mathrm{CD} 29^{\mathrm{lo}} / \mathrm{CD} 24^{+} / \mathrm{CD} 61^{-}$subset does (Vaillant et al. 2008). Furthermore, the $\alpha 6$ integrin subunit CD49f is a biomarker for TICs in $\mathrm{ER}^{-}$and TNBC xenografts (Meyer et al. 2010, Lee et al. 2014). Recently, an autocrine loop between VEGF and integrin signaling has been uncovered in breast TICs. In this loop, VEGF signaling activates $\alpha 6 \beta 1$ (CD49fCD29) integrin, which enhances the expression of Gli and leads to the transcription of the VEGF receptor neuropilin 2 (Goel et al. 2013). Another study demonstrated that VEGF signaling transcriptionally regulates an RNA-splicing factor that regulates the splicing of $\alpha 6 \mathrm{~B} \beta 1$ (CD49fBCD29) integrin. This splice form of $\alpha 6 \beta 1$ (CD49fCD29) integrin defines a mesenchymal-like subpopulation within the $\mathrm{CD} 44^{\text {high }} / \mathrm{CD} 24^{\text {low }}$ cells, and it is critical for breast TIC function (Goel et al. 2014). Also recently, the integrin $\alpha(\mathrm{v}) \beta 3(\alpha(\mathrm{v}) \mathrm{CD} 61)$ and the KRAS/NFKB signaling pathway were shown to drive resistance to EGFR inhibition in breast TICs (Seguin et al. 2014), which suggests that integrin proteins have a function in breast TICs.

In addition, focal adhesion kinase (FAK) is a major mediator of integrin signaling. Targeted deletion of Fak in mouse mammary epithelium decreases the content of $\mathrm{ALDH}^{+}$stem-like populations in primary MMTV-PyMT mammary tumors, and it decreases the tumorigenicity of $\mathrm{ALDH}^{+}$cells in vivo (Luo et al. 2009). Functional studies show that integrin signaling actively maintains the mammary cancer stem/progenitor population (Luo et al. 2009). Further studies have suggested that FAK plays a distinct role in mammary stem cells and progenitors and that it plays correspondingly different roles in claudinlow- and luminal-like-type breast cancer cells, which suggests a potential relationship between normal stem cells/progenitors and different subtypes of breast cancers (Luo et al. 2013). Together, these recent discoveries of detailed mechanisms that involve integrin signaling in breast TICs provide novel intervention opportunities.

Treatment with anti- $\beta 1$ integrin antibodies enhances the response of human xenograft breast tumors to radiotherapies (Park et al. 2008) and normalizes structures of breast cancer cell lines in 3D cultures (Park et al. 2006). In addition, the recent finding that integrin signaling in breast TICs drives resistance to EGFR inhibitors suggests potential novel strategies for sensitizing breast tumors to receptor tyrosine kinase inhibition (Seguin et al. 2014). Cilengitide, an integrin antagonist currently being tested in clinical trials (Goodman \& Picard 2012), has been shown to reduce bone metastasis in a mouse mammary tumor model (Bauerle et al. 2011). A more recent study also reported that the increased stiffness of the extracellular matrix in tumors can activate integrin signaling to drive tumor progression, which suggests another new intervention method (Mouw et al. 2014).

\section{MicroRNAs}

MicroRNAs (miRNAs) are short, noncoding RNAs that bind to complementary sequences in mRNAs, which results in the suppression of translation and/or degradation of targeted mRNAs (Bartel 2009). Importantly, more than 30 miRNAs have been reported as being differentially expressed between breast TICs and non-TICs (Shimono et al. 2009), which suggests that miRNAs may function to regulate breast TICs. Indeed, let-7 family members are down-regulated in mammospheres formed from primary breast tumor cells as compared to bulk tumor cells, and forced expression of let-7a reduces MSFE (Yu et al. 2007). miR-200 family members are also down-regulated in $\mathrm{CD} 44^{+} / \mathrm{CD} 24^{-}$cells, and forced expression of miR-200c reduces tumor-initiating capacity (Shimono et al. 2009). Interestingly, miR-93 is highly expressed in non-TICs in claudin-low-type breast cancer, but it is not differentially expressed between TICs and non-TICs in luminal-type breast cancer. Forced expression of miR-93 decreases the TIC frequency in claudin-low-type tumors, whereas it increases the TIC frequency in luminal-type tumors, which suggests that the same miRNA can play distinct roles in regulating TICs in different types of breast cancer (Liu et al. 2012). Moreover, Lin28, a negative regulator of let-7, is a direct target of the WNT- $\beta$-catenin pathway. Loss of function of Lin28 reverses WNT-mediated let-7 inhibition and breast TIC expansion (Cai et al. 2013). These data suggest that miRNAs can be mediators of WNT-regulated breast TIC function, and as such, they are promising targets for inhibiting breast TIC expansion. Taken together, these data suggest that miRNAs could be useful agents to target for the treatment of breast cancer.

Inhibition of miRNAs can be achieved by i.v. injection of antagomirs, which are modified antisense oligos that are complementary to the miRNA sequence (Krutzfeldt et al. 2005). In one example, anti-let-7 oligos were introduced

Published by Bioscientifica Ltd. 


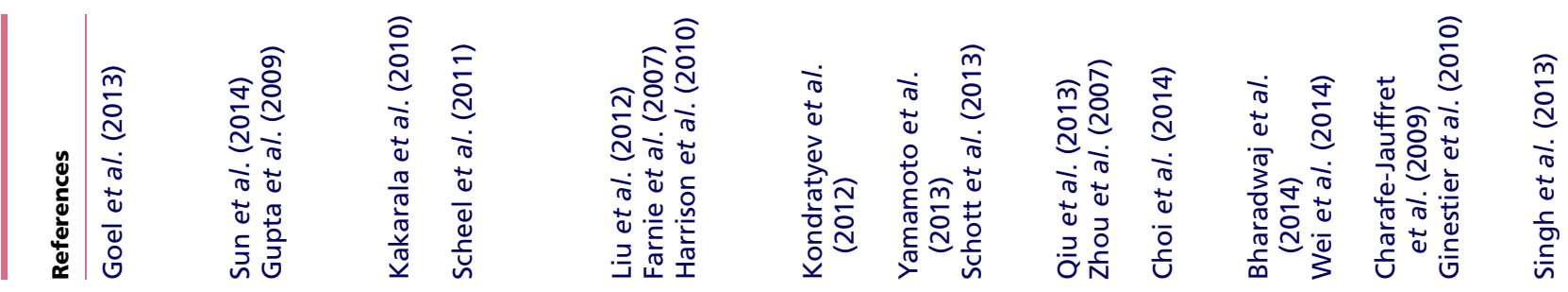

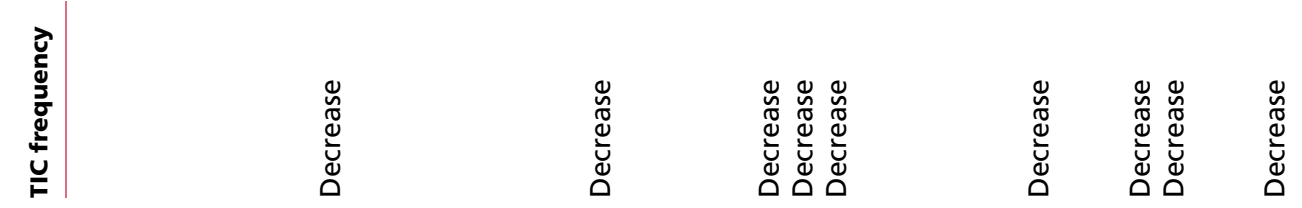

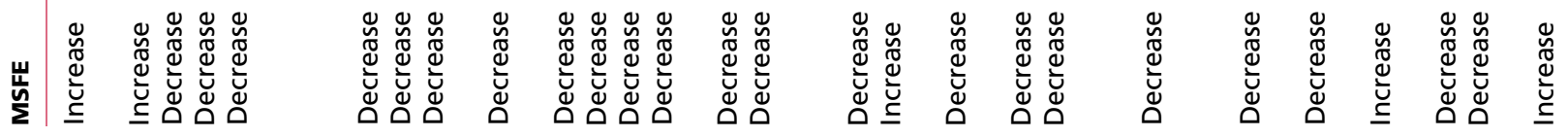



垔

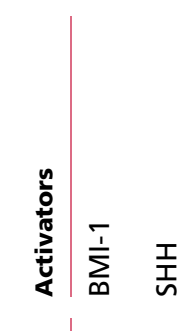

হ̦

$\stackrel{\infty}{=}$

$\stackrel{\infty}{=}$

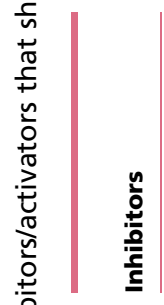

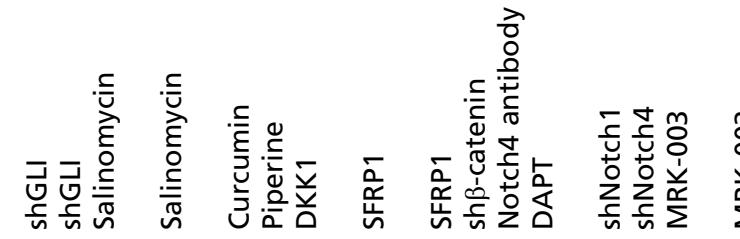

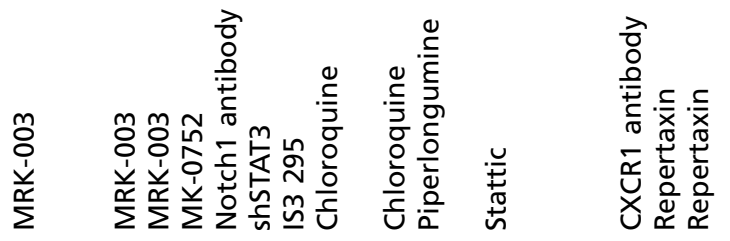
$\frac{\tilde{c}}{\mathrm{a}} \overline{\frac{n}{4}}$

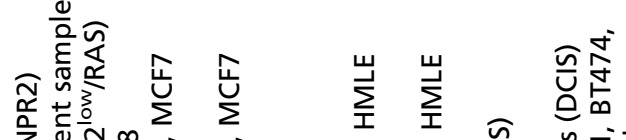

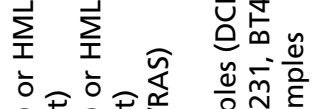

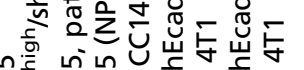





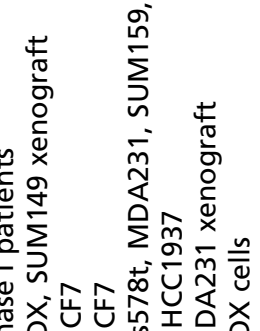



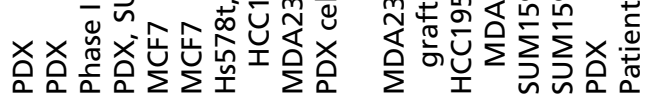






http://erc.endocrinology-journals.org DOI: 10.1530/ERC-14-0447
(C) 2015 Society for Endocrinology Printed in Great Britain into breast cancer cells, which resulted in the enhanced self-renewal of non-TICs (Yu et al. 2007). Alternatively, synthesized artificial miRNAs that mimic the effect of a miRNA can be introduced. For instance, when let-7 mimics were administered to mouse models of lung cancer, they led to reduced tumor growth (Esquela-Kerscher et al. 2008). However, targeting breast TICs by manipulating miRNAs remains challenging. One problem is that each miRNA potentially regulates hundreds of genes simultaneously, which leads to poor specificity. Also, cancer cells tend to produce mRNAs with shorter 3 '-UTRs, which often contain the miRNA target sites, and that makes them resistant to miRNA mimics (Mayr \& Bartel 2009).

Panels of inhibitors/activators have been developed for each of the signaling pathways mentioned earlier in the present report. To evaluate their proposed effects on TICs, MSFE, and LDT assays should be applied to measure their efficiency. We provided a summary of the activatory and inhibitory agents that target those signaling pathways in Table 3, emphasizing their effectiveness on TIC function.

\section{Summary}

The hypothesized existence of resistant breast TICs provides a potential mechanism for explaining treatment failure, recurrence, and metastasis in the treatment of breast cancer using current therapeutic methods. Therefore, inhibiting the pathways that are essential for breast TIC function is a promising strategy for overcoming drug resistance. Furthermore, combining conventional therapies with breast TIC-targeting drugs should improve longterm patient outcome by eliminating TICs, which potentiate future recurrence and metastasis. Moreover, effective therapeutic strategies should address concerns regarding the dynamic properties of breast TICs, such as their plasticity and their enhanced metastatic potential, which could become problematic during breast cancer treatment. Finally, although simply targeting one major signaling pathway is unlikely to eliminate breast TICs completely, sequential or simultaneous administration of inhibitors that target multiple signaling pathways may render long-lasting and synergistic effects on TICs. Alternatively, given our success in eliminating non-TICs, inducing the differentiation of TICs to other cell types by manipulating essential signaling pathways, and then employing conventional therapies, could be a safe and effective strategy. Nonetheless, genome instability in stem-like cells predicts that TICs are evolving entities that quickly adapt to alternative survival mechanisms. We

Published by Bioscientifica Ltd. 
will have to continue to build on our knowledge about breast TICs by revealing the novel mechanisms and alternative signaling pathways that are essential for their maintenance and function.

\section{Declaration of interest}

M T Lewis is a scientific founder and limited partner in StemMed Ltd and is a manager of StemMed holdings LLC.

\section{Funding}

The authors were supported in part by the NIH (grant number R01 CA127857 to M T Lewis), the $\mathrm{NIH} / \mathrm{NCl}$ (grant number U54 CA149196 to M T Lewis), the DOD (pre-doctoral grant number W81XWH-11-1-0093 to W Wei), the Baylor College of Medicine Dan L. Duncan Cancer Center (grant number P30-CA125123 to Dr C Kent Osborne and a pilot grant to W Wei).

\section{Acknowledgements}

The authors thank Yi Li, Teresa Monkkonen, Mothaffar F Rimawi, Jeffrey M Rosen, Amy N Shore, and David J Tweardy for their critical comments as well as Amy N Shore and Miller Anastasia for their editorial assistance.

\section{References}

Early Breast Cancer Trialists' Collaborative Group 1998 Polychemotherapy for early breast cancer: an overview of the randomised trials. Lancet $\mathbf{3 5 2}$ 930-942. (doi:10.1016/S0140-6736(98)03301-7)

Abd El-Rehim DM, Pinder SE, Paish CE, Bell J, Blamey RW, Robertson JF, Nicholson RI \& Ellis IO 2004 Expression of luminal and basal cytokeratins in human breast carcinoma. Journal of Pathology 203 661-671. (doi:10.1002/path.1559)

Al-Hajj M, Wicha MS, Benito-Hernandez A, Morrison SJ \& Clarke MF 2003 Prospective identification of tumorigenic breast cancer cells. PNAS $\mathbf{1 0 0}$ 3983-3988. (doi:10.1073/pnas.0530291100)

Allred DC 2010 Issues and updates: evaluating estrogen receptor- $\alpha$, progesterone receptor, and HER2 in breast cancer. Modern Pathology 23 (Suppl 2) S52-S59. (doi:10.1038/modpathol.2010.55)

van Amerongen R, Bowman AN \& Nusse R 2012 Developmental stage and time dictate the fate of $\mathrm{Wnt} / \beta$-catenin-responsive stem cells in the mammary gland. Cell Stem Cell 11 387-400. (doi:10.1016/j.stem.2012. 05.023)

Anastas JN \& Moon RT 2013 WNT signalling pathways as therapeutic targets in cancer. Nature Reviews. Cancer 13 11-26. (doi:10.1038/ nrc3419)

Andl T, Reddy ST, Gaddapara T \& Millar SE 2002 WNT signals are required for the initiation of hair follicle development. Developmental Cell 2 643-653. (doi:10.1016/S1534-5807(02)00167-3)

Armanious H, Gelebart P, Mackey J, Ma Y \& Lai R 2010 STAT3 upregulates the protein expression and transcriptional activity of $\beta$-catenin in breast cancer. International Journal of Clinical and Experimental Pathology 3 654-664.

Atkinson RL, Zhang M, Diagaradjane P, Peddibhotla S, Contreras A, Hilsenbeck SG, Woodward WA, Krishnan S, Chang JC \& Rosen JM 2010 Thermal enhancement with optically activated gold nanoshells sensitizes breast cancer stem cells to radiation therapy. Science Translational Medicine 2 55ra79. (doi:10.1126/scitranslmed.3001447)

de Azambuja E, Holmes AP, Piccart-Gebhart M, Holmes E, Di Cosimo S, Swaby RF, Untch M, Jackisch C, Lang I, Smith I et al. 2014 Lapatinib with trastuzumab for HER2-positive early breast cancer (NeoALTTO): survival outcomes of a randomised, open-label, multicentre, phase 3 trial and their association with pathological complete response. Lancet Oncology 15 1137-1146. (doi:10.1016/S1470-2045(14)70320-1)

Azzam DJ, Zhao D, Sun J, Minn AJ, Ranganathan P, Drews-Elger K, Han X, Picon-Ruiz M, Gilbert CA, Wander SA et al. 2013 Triple negative breast cancer initiating cell subsets differ in functional and molecular characteristics and in $\gamma$-secretase inhibitor drug responses. EMBO Molecular Medicine 5 1502-1522. (doi:10.1002/ emmm.201302558)

Bandyopadhyay A, Wang L, Agyin J, Tang Y, Lin S, Yeh IT, De K \& Sun L-Z 2010 Doxorubicin in combination with a small TGF $\beta$ inhibitor: a potential novel therapy for metastatic breast cancer in mouse models. PLOS ONE 5 e10365. (doi:10.1371/journal.pone.0010365)

Bartel DP 2009 MicroRNAs: target recognition and regulatory functions. Cell 136 215-233. (doi:10.1016/j.cell.2009.01.002)

Battula VL, Shi Y, Evans KW, Wang RY, Spaeth EL, Jacamo RO, Guerra R, Sahin AA, Marini FC, Hortobagyi G et al. 2012 Ganglioside GD2 identifies breast cancer stem cells and promotes tumorigenesis Journal of Clinical Investigation 122 2066-2078. (doi:10.1172/JCI59735)

Bauerle T, Komljenovic D, Merz M, Berger MR, Goodman SL \& Semmler W 2011 Cilengitide inhibits progression of experimental breast cancer bone metastases as imaged noninvasively using VCT, MRI and DCEMRI in a longitudinal in vivo study. International Journal of Cancer. Journal International du Cancer 128 2453-2462. (doi:10.1002/ijc.25563)

Bharadwaj U, Eckols TK, Kolosov M, Kasembeli MM, Adam A, Torres D, Zhang X, Dobrolecki LE, Wei W, Lewis MT et al. 2015 Drug-repositioning screening identified piperlongumine as a direct STAT3 inhibitor with potent activity against breast cancer. Oncogene $\mathbf{3 4}$ 1341-1353. (doi:10.1038/onc.2014.72)

Bhola NE, Balko JM, Dugger TC, Kuba MG, Sanchez V, Sanders M, Stanford J, Cook RS \& Arteaga CL 2013 TGF- $\beta$ inhibition enhances chemotherapy action against triple-negative breast cancer. Journal of Clinical Investigation 123 1348-1358. (doi:10.1172/JCI65416)

Bieche I, Chavey C, Andrieu C, Busson M, Vacher S, Le Corre L, Guinebretiere JM, Burlinchon S, Lidereau R \& Lazennec G 2007 CXC chemokines located in the $4 \mathrm{q} 21$ region are up-regulated in breast cancer. Endocrine-Related Cancer 14 1039-1052. (doi:10.1677/ erc.1.01301)

Brabletz T, Jung A, Spaderna S, Hlubek F \& Kirchner T 2005 Opinion: migrating cancer stem cells - an integrated concept of malignant tumour progression. Nature Reviews. Cancer 5 744-749. (doi:10.1038/ nrc1694)

Bray SJ 2006 Notch signalling: a simple pathway becomes complex. Nature Reviews. Molecular Cell Biology 7 678-689. (doi:10.1038/nrm2009)

Burstein HJ, Temin S, Anderson H, Buchholz TA, Davidson NE, Gelmon KE, Giordano SH, Hudis CA, Rowden D, Solky AJ et al. 2014 Adjuvant endocrine therapy for women with hormone receptor-positive breast cancer: american society of clinical oncology clinical practice guideline focused update. Journal of Clinical Oncology 32 2255-2269. (doi:10.1200/JCO.2013.54.2258)

Cai WY, Wei TZ, Luo QC, Wu QW, Liu QF, Yang M, Ye GD, Wu JF, Chen YY, Sun GB et al. 2013 The Wnt- $\beta$-catenin pathway represses let-7 microRNA expression through transactivation of Lin28 to augment breast cancer stem cell expansion. Journal of Cell Science 126 2877-2889. (doi:10.1242/jcs.123810)

Chaffer CL, Brueckmann I, Scheel C, Kaestli AJ, Wiggins PA, Rodrigues LO, Brooks M, Reinhardt F, Su Y, Polyak K et al. 2011 Normal and neoplastic nonstem cells can spontaneously convert to a stem-like state. PNAS $\mathbf{1 0 8}$ 7950-7955. (doi:10.1073/pnas.1102454108)

Chaffer CL, Marjanovic ND, Lee T, Bell G, Kleer CG, Reinhardt F, D'Alessio AC, Young RA \& Weinberg RA 2013 Poised chromatin at the ZEB1 promoter enables breast cancer cell plasticity and enhances tumorigenicity. Cell 154 61-74. (doi:10.1016/j.cell.2013.06.005)

Chakrabarty A, Bhola NE, Sutton C, Ghosh R, Kuba MG, Dave B, Chang JC \& Arteaga CL 2013 Trastuzumab-resistant cells rely on a HER2-PI3K- 
FoxO-survivin axis and are sensitive to PI3K inhibitors. Cancer Research 73 1190-1200. (doi:10.1158/0008-5472.CAN-12-2440)

Charafe-Jauffret E, Ginestier C, Iovino F, Wicinski J, Cervera N, Finetti P, Hur MH, Diebel ME, Monville F, Dutcher J et al. 2009 Breast cancer cell lines contain functional cancer stem cells with metastatic capacity and a distinct molecular signature. Cancer Research 69 1302-1313. (doi:10.1158/0008-5472.CAN-08-2741)

Chatterjee-Kishore M, van den Akker F \& Stark GR 2000 Association of STATs with relatives and friends. Trends in Cell Biology 10 106-111. (doi:10.1016/S0962-8924(99)01709-2)

Chen MS, Woodward WA, Behbod F, Peddibhotla S, Alfaro MP, Buchholz TA \& Rosen JM $2007 \mathrm{Wnt} / \beta$-catenin mediates radiation resistance of Sca1 + progenitors in an immortalized mammary gland cell line. Journal of Cell Science 120 468-477. (doi:10.1242/jcs.03348)

Cho RW, Wang X, Diehn M, Shedden K, Chen GY, Sherlock G, Gurney A, Lewicki J \& Clarke MF 2008 Isolation and molecular characterization of cancer stem cells in MMTV-Wnt-1 murine breast tumors. Stem Cells $\mathbf{2 6}$ 364-371. (doi:10.1634/stemcells.2007-0440)

Choi DS, Blanco E, Kim YS, Rodriguez AA, Zhao H, Huang TH, Chen CL, Jin G, Landis MD, Burey LA et al. 2014 Chloroquine eliminates cancer stem cells through deregulation of Jak2 and DNMT1. Stem Cells 32 2309-2323. (doi:10.1002/stem.1746)

Chung A, Cui X, Audeh W \& Giuliano A 2013 Current status of anti-human epidermal growth factor receptor 2 therapies: predicting and overcoming herceptin resistance. Clinical Breast Cancer 13 223-232. (doi:10.1016/j.clbc.2013.04.001)

Cicalese A, Bonizzi G, Pasi CE, Faretta M, Ronzoni S, Giulini B, Brisken C, Minucci S, Di Fiore PP \& Pelicci PG 2009 The tumor suppressor p53 regulates polarity of self-renewing divisions in mammary stem cells. Cell 138 1083-1095. (doi:10.1016/j.cell.2009.06.048)

Clarke RB, Howell A, Potten CS \& Anderson E 1997 Dissociation between steroid receptor expression and cell proliferation in the human breast. Cancer Research 57 4987-4991.

Clarke R, Liu MC, Bouker KB, Gu Z, Lee RY, Zhu Y, Skaar TC, Gomez B, O'Brien K, Wang Y et al. 2003 Antiestrogen resistance in breast cancer and the role of estrogen receptor signaling. Oncogene 22 7316-7339. (doi:10.1038/sj.onc.1206937)

Cleary AS, Leonard TL, Gestl SA \& Gunther EJ 2014 Tumour cell heterogeneity maintained by cooperating subclones in Wnt-driven mammary cancers. Nature $\mathbf{5 0 8} 113-117$. (doi:10.1038/nature13187)

Cortazar P, Zhang L, Untch M, Mehta K, Costantino JP, Wolmark N, Bonnefoi H, Cameron D, Gianni L, Valagussa P et al. 2014 Pathological complete response and long-term clinical benefit in breast cancer: the CTNeoBC pooled analysis. Lancet 384 164-172. (doi:10.1016/ S0140-6736(13)62422-8)

Creighton CJ, Li X, Landis M, Dixon JM, Neumeister VM, Sjolund A, Rimm DL, Wong H, Rodriguez A, Herschkowitz JI et al. 2009 Residual breast cancers after conventional therapy display mesenchymal as well as tumor-initiating features. PNAS 106 13820-13825. (doi:10.1073/pnas. 0905718106)

Croker AK, Goodale D, Chu J, Postenka C, Hedley BD, Hess DA \& Allan AL 2009 High aldehyde dehydrogenase and expression of cancer stem cell markers selects for breast cancer cells with enhanced malignant and metastatic ability. Journal of Cellular and Molecular Medicine $\mathbf{1 3}$ 2236-2252. (doi:10.1111/j.1582-4934.2008.00455.x)

Ding K, Banerjee A, Tan S, Zhao J, Zhuang Q, Li R, Qian P, Liu S, Wu ZS, Lobie PE et al. 2014 Artemin, a member of the glial cell line-derived neurotrophic factor family of ligands, is HER2-regulated and mediates acquired trastuzumab resistance by promoting cancer stem cell-like behavior in mammary carcinoma cells. Journal of Biological Chemistry 289 16057-16071. (doi:10.1074/jbc.M113.529552)

Dontu G, Abdallah WM, Foley JM, Jackson KW, Clarke MF, Kawamura MJ \& Wicha MS 2003 In vitro propagation and transcriptional profiling of human mammary stem/progenitor cells. Genes and Development 17 1253-1270. (doi:10.1101/gad.1061803)
Dontu G, Jackson KW, McNicholas E, Kawamura MJ, Abdallah WM \& Wicha MS 2004 Role of Notch signaling in cell-fate determination of human mammary stem/progenitor cells. Breast Cancer Research 6 R605-R615. (doi:10.1186/bcr920)

Dowsett M, Johnston S, Martin LA, Salter J, Hills M, Detre S, Gutierrez MC, Mohsin SK, Shou J, Allred DC et al. 2005 Growth factor signalling and response to endocrine therapy: the Royal Marsden Experience. Endocrine-Related Cancer 12 (Suppl 1) S113-S117. (doi:10.1677/erc.1. 01044)

Dowsett M, Houghton J, Iden C, Salter J, Farndon J, A'Hern R, Sainsbury R $\&$ Baum M 2006 Benefit from adjuvant tamoxifen therapy in primary breast cancer patients according oestrogen receptor, progesterone receptor, EGF receptor and HER2 status. Annals of Oncology 17 818-826. (doi:10.1093/annonc/mdl016)

Doyle LA, Yang W, Abruzzo LV, Krogmann T, Gao Y, Rishi AK \& Ross DD 1998 A multidrug resistance transporter from human MCF-7 breast cancer cells. PNAS 95 15665-15670. (doi:10.1073/pnas.95.26.15665)

Driever W \& Nusslein-Volhard C 1988 The bicoid protein determines position in the Drosophila embryo in a concentration-dependent manner. Cell 54 95-104. (doi:10.1016/0092-8674(88)90183-3)

Early Breast Cancer Trialists' Collaborative Group (EBCTCG) 2005 Effects of chemotherapy and hormonal therapy for early breast cancer on recurrence and 15-year survival: an overview of the randomised trials. Lancet 365 1687-1717. (doi:10.1016/S0140-6736(05)66544-0)

Esquela-Kerscher A, Trang P, Wiggins JF, Patrawala L, Cheng A, Ford L, Weidhaas JB, Brown D, Bader AG \& Slack FJ 2008 The let-7 microRNA reduces tumor growth in mouse models of lung cancer. Cell Cycle $\mathbf{7}$ 759-764. (doi:10.4161/cc.7.6.5834)

Farnie G, Clarke RB, Spence K, Pinnock N, Brennan K, Anderson NG \& Bundred NJ 2007 Novel cell culture technique for primary ductal carcinoma in situ: role of Notch and epidermal growth factor receptor signaling pathways. Journal of the National Cancer Institute 99 616-627. (doi:10.1093/jnci/djk133)

Fehm T, Krawczyk N, Solomayer EF, Becker-Pergola G, Durr-Storzer S, Neubauer H, Seeger H, Staebler A, Wallwiener D \& Becker S 2008 ER $\alpha$ status of disseminated tumour cells in bone marrow of primary breast cancer patients. Breast Cancer Research 10 R76. (doi:10.1186/bcr2143)

Feng W, Gentles A, Nair RV, Huang M, Lin Y, Lee CY, Cai S, Scheeren FA, Kuo AH \& Diehn M 2014 Targeting unique metabolic properties of breast tumor initiating cells. Stem Cells 32 1734-1745. (doi:10.1002/ stem.1662)

Fillmore CM \& Kuperwasser C 2008 Human breast cancer cell lines contain stem-like cells that self-renew, give rise to phenotypically diverse progeny and survive chemotherapy. Breast Cancer Research 10 R25. (doi:10.1186/bcr1982)

Fillmore CM, Gupta PB, Rudnick JA, Caballero S, Keller PJ, Lander ES \& Kuperwasser C 2010 Estrogen expands breast cancer stem-like cells through paracrine FGF/Tbx3 signaling. PNAS 107 21737-21742. (doi:10.1073/pnas.1007863107)

Gallahan D \& Callahan R 1987 Mammary tumorigenesis in feral mice: identification of a new int locus in mouse mammary tumor virus (Czech II)-induced mammary tumors. Journal of Virology 61 66-74.

Gallahan D \& Callahan R 1997 The mouse mammary tumor associated gene INT3 is a unique member of the NOTCH gene family (NOTCH4). Oncogene 14 1883-1890. (doi:10.1038/sj.onc.1201035)

Garcia-Zaragoza E, Perez-Tavarez R, Ballester A, Lafarga V, Jimenez-Reinoso A, Ramirez A, Murillas R \& Gallego MI 2012 Intraepithelial paracrine hedgehog signaling induces the expansion of ciliated cells that express diverse progenitor cell markers in the basal epithelium of the mouse mammary gland. Developmental Biology 372 28-44. (doi:10.1016/ j.ydbio.2012.09.005)

Ghebeh H, Sleiman G, Manogaran P, Al-Mazrou A, Barhoush E, Al-Mohanna F, Tulbah A, Al-Faqeeh K \& Adra C 2013 Profiling of normal and malignant breast tissue show CD44high/CD24low phenotype as a predominant stem/progenitor marker when used in

Published by Bioscientifica Ltd. 
combination with Ep-CAM/CD49f markers. BMC Cancer 13289. (doi:10.1186/1471-2407-13-289)

Gianni L, Pienkowski T, Im YH, Roman L, Tseng LM, Liu MC, Lluch A, Staroslawska E, de la Haba-Rodriguez J, Im SA et al. 2012 Efficacy and safety of neoadjuvant pertuzumab and trastuzumab in women with locally advanced, inflammatory, or early HER2-positive breast cancer (NeoSphere): a randomised multicentre, open-label, phase 2 trial. Lancet Oncology 13 25-32. (doi:10.1016/S1470-2045(11)70336-9)

Giltnane JM, Ryden L, Cregger M, Bendahl PO, Jirstrom K \& Rimm DL 2007 Quantitative measurement of epidermal growth factor receptor is a negative predictive factor for tamoxifen response in hormone receptor positive premenopausal breast cancer. Journal of Clinical Oncology 25 3007-3014. (doi:10.1200/JCO.2006.08.9938)

Ginestier C, Hur MH, Charafe-Jauffret E, Monville F, Dutcher J, Brown M, Jacquemier J, Viens P, Kleer CG, Liu S et al. 2007 ALDH1 is a marker of normal and malignant human mammary stem cells and a predictor of poor clinical outcome. Cell Stem Cell 1 555-567. (doi:10.1016/ j.stem.2007.08.014)

Ginestier C, Liu S, Diebel ME, Korkaya H, Luo M, Brown M, Wicinski J, Cabaud O, Charafe-Jauffret E, Birnbaum D et al. 2010 CXCR1 blockade selectively targets human breast cancer stem cells in vitro and in xenografts. Journal of Clinical Investigation 120 485-497. (doi:10.1172/ JCI39397)

Goel HL, Pursell B, Chang C, Shaw LM, Mao J, Simin K, Kumar P, Vander Kooi CW, Shultz LD, Greiner DL et al. 2013 GLI1 regulates a novel neuropilin-2/ $\alpha 6 \beta 1$ integrin based autocrine pathway that contributes to breast cancer initiation. EMBO Molecular Medicine 5 488-508. (doi:10.1002/emmm.201202078)

Goel HL, Gritsko T, Pursell B, Chang C, Shultz LD, Greiner DL, Norum JH, Toftgard R, Shaw LM \& Mercurio AM 2014 Regulated splicing of the $\alpha 6$ integrin cytoplasmic domain determines the fate of breast cancer stem cells. Cell Reports 7 747-761. (doi:10.1016/j.celrep.2014.03.059)

Goodell MA, Brose K, Paradis G, Conner AS \& Mulligan RC 1996 Isolation and functional properties of murine hematopoietic stem cells that are replicating in vivo. Journal of Experimental Medicine 183 1797-1806. (doi:10.1084/jem.183.4.1797)

Goodman SL \& Picard M 2012 Integrins as therapeutic targets. Trends in Pharmacological Sciences 33 405-412. (doi:10.1016/j.tips.2012.04.002)

Gupta PB, Onder TT, Jiang G, Tao K, Kuperwasser C, Weinberg RA \& Lander ES 2009 Identification of selective inhibitors of cancer stem cells by high-throughput screening. Cell 138 645-659. (doi:10.1016/j.cell. 2009.06.034)

Gupta PB, Fillmore CM, Jiang G, Shapira SD, Tao K, Kuperwasser C \& Lander ES 2011 Stochastic state transitions give rise to phenotypic equilibrium in populations of cancer cells. Cell 146 633-644. (doi:10.1016/j.cell.2011.07.026)

Hammond ME, Hayes DF \& Wolff AC 2011 Clinical notice for American Society of Clinical Oncology-College of American Pathologists guideline recommendations on ER/PgR and HER2 testing in breast cancer. Journal of Clinical Oncology 29 e458. (doi:10.1200/JCO.2011.35.2245)

Hanker AB, Pfefferle AD, Balko JM, Kuba MG, Young CD, Sanchez V, Sutton CR, Cheng H, Perou CM, Zhao JJ et al. 2013 Mutant PIK3CA accelerates HER2-driven transgenic mammary tumors and induces resistance to combinations of anti-HER2 therapies. PNAS 110 14372-14377. (doi:10.1073/pnas.1303204110)

Harrison H, Farnie G, Howell SJ, Rock RE, Stylianou S, Brennan KR, Bundred NJ \& Clarke RB 2010 Regulation of breast cancer stem cell activity by signaling through the Notch 4 receptor. Cancer Research 70 709-718. (doi:10.1158/0008-5472.CAN-09-1681)

Harrison H, Simoes BM, Rogerson L, Howell SJ, Landberg G \& Clarke RB 2013 Oestrogen increases the activity of oestrogen receptor negative breast cancer stem cells through paracrine EGFR and Notch signalling. Breast Cancer Research 15 R21. (doi:10.1186/bcr3396)

Harvey JM, Clark GM, Osborne CK \& Allred DC 1999 Estrogen receptor status by immunohistochemistry is superior to the ligand-binding assay for predicting response to adjuvant endocrine therapy in breast cancer. Journal of Clinical Oncology 171474.

Haughian JM, Pinto MP, Harrell JC, Bliesner BS, Joensuu KM, Dye WW, Sartorius CA, Tan AC, Heikkila P, Perou CM et al. 2012 Maintenance of hormone responsiveness in luminal breast cancers by suppression of Notch. PNAS 109 2742-2747. (doi:10.1073/pnas.1106509108)

Heldin CH, Miyazono K \& ten Dijke P 1997 TGF- $\beta$ signalling from cell membrane to nucleus through SMAD proteins. Nature $390465-471$. (doi:10.1038/37284)

Herschkowitz J, Simin K, Weigman V, Mikaelian I, Usary J, Hu Z, Rasmussen K, Jones L, Assefnia S, Chandrasekharan S et al. 2007 Identification of conserved gene expression features between murine mammary carcinoma models and human breast tumors. Genome Biology 8 R76. (doi:10.1186/gb-2007-8-5-r76)

Herschkowitz JI, Zhao W, Zhang M, Usary J, Murrow G, Edwards D, Knezevic J, Greene SB, Darr D, Troester MA et al. 2012 Comparative oncogenomics identifies breast tumors enriched in functional tumorinitiating cells. PNAS 109 2778-2783. (doi:10.1073/pnas.1018862108)

Hirschmann-Jax C, Foster AE, Wulf GG, Nuchtern JG, Jax TW, Gobel U, Goodell MA \& Brenner MK 2004 A distinct "side population" of cells with high drug efflux capacity in human tumor cells. PNAS $\mathbf{1 0 1}$ 14228-14233. (doi:10.1073/pnas.0400067101)

Hollier BG, Tinnirello AA, Werden SJ, Evans KW, Taube JH, Sarkar TR, Sphyris N, Shariati M, Kumar SV, Battula VL et al. 2013 FOXC2 expression links epithelial-mesenchymal transition and stem cell properties in breast cancer. Cancer Research 73 1981-1992. (doi:10. 1158/0008-5472.CAN-12-2962)

Howell A \& Wardley AM 2005 Overview of the impact of conventional systemic therapies on breast cancer. Endocrine-Related Cancer 12 (Suppl 1) S9-S16. (doi:10.1677/erc.1.01003)

Iliopoulos D, Hirsch HA, Wang G \& Struhl K 2011 Inducible formation of breast cancer stem cells and their dynamic equilibrium with non-stem cancer cells via IL6 secretion. PNAS 108 1397-1402. (doi:10.1073/pnas. 1018898108)

Ingham PW \& McMahon AP 2001 Hedgehog signaling in animal development: paradigms and principles. Genes and Development 15 3059-3087. (doi:10.1101/gad.938601)

Ithimakin S, Day KC, Malik F, Zen Q, Dawsey SJ, Bersano-Begey TF, Quraishi AA, Ignatoski KW, Daignault S, Davis A et al. 2013 HER2 drives luminal breast cancer stem cells in the absence of HER2 amplification: implications for efficacy of adjuvant trastuzumab. Cancer Research 73 1635-1646. (doi:10.1158/0008-5472.CAN-12-3349)

James D, Levine AJ, Besser D \& Hemmati-Brivanlou A 2005 TGF $\beta /$ activin/nodal signaling is necessary for the maintenance of pluripotency in human embryonic stem cells. Development 132 1273-1282. (doi:10.1242/dev.01706)

Jensen EV \& Jordan VC 2003 The estrogen receptor: a model for molecular medicine. Clinical Cancer Research 9 1980-1989.

Johnston SR \& Dowsett M 2003 Aromatase inhibitors for breast cancer: lessons from the laboratory. Nature Reviews. Cancer 3 821-831. (doi: $10.1038 /$ nrc1211)

Kakarala M, Brenner DE, Korkaya H, Cheng C, Tazi K, Ginestier C, Liu S, Dontu G \& Wicha MS 2010 Targeting breast stem cells with the cancer preventive compounds curcumin and piperine. Breast Cancer Research and Treatment 122 777-785. (doi:10.1007/s10549-009-0612-x)

Kim S-Y, Kang JW, Song X, Kim BK, Yoo YD, Kwon YT \& Lee YJ 2013 Role of the IL-6-JAK1-STAT3-Oct-4 pathway in the conversion of non-stem cancer cells into cancer stem-like cells. Cellular Signalling 25 961-969. (doi:10.1016/j.cellsig.2013.01.007)

Knowlden JM, Hutcheson IR, Jones HE, Madden T, Gee JM, Harper ME, Barrow D, Wakeling AE \& Nicholson RI 2003 Elevated levels of epidermal growth factor receptor/c-erbB2 heterodimers mediate an autocrine growth regulatory pathway in tamoxifen-resistant MCF-7 cells. Endocrinology 144 1032-1044. (doi:10.1210/en.2002-220620)

Kondratyev M, Kreso A, Hallett RM, Girgis-Gabardo A, Barcelon ME, Ilieva D, Ware C, Majumder PK \& Hassell JA 2012 Gamma-secretase inhibitors

Published by Bioscientifica Ltd. 
target tumor-initiating cells in a mouse model of ERBB2 breast cancer. Oncogene 31 93-103. (doi:10.1038/onc.2011.212)

Korkaya H, Paulson A, Iovino F \& Wicha MS 2008 HER2 regulates the mammary stem/progenitor cell population driving tumorigenesis and invasion. Oncogene 27 6120-6130. (doi:10.1038/onc.2008.207)

Korkaya H, Paulson A, Charafe-Jauffret E, Ginestier C, Brown M, Dutcher J, Clouthier SG \& Wicha MS 2009 Regulation of mammary stem/progenitor cells by PTEN/Akt/ $\beta$-catenin signaling. PLoS Biology 7 e1000121. (doi:10.1371/journal.pbio.1000121)

Korkaya H, Kim GI, Davis A, Malik F, Henry NL, Ithimakin S, Quraishi AA, Tawakkol N, D'Angelo R, Paulson AK et al. 2012 Activation of an IL6 inflammatory loop mediates trastuzumab resistance in HER2 + breast cancer by expanding the cancer stem cell population. Molecular Cell $\mathbf{4 7}$ 570-584. (doi:10.1016/j.molcel.2012.06.014)

Krutzfeldt J, Rajewsky N, Braich R, Rajeev KG, Tuschl T, Manoharan M \& Stoffel M 2005 Silencing of microRNAs in vivo with 'antagomirs'. Nature 438 685-689. (doi:10.1038/nature04303)

Lan KH, Lu CH \& Yu D 2005 Mechanisms of trastuzumab resistance and their clinical implications. Annals of the New York Academy of Sciences 1059 70-75. (doi:10.1196/annals.1339.026)

Langlands FE, Horgan K, Dodwell DD \& Smith L 2013 Breast cancer subtypes: response to radiotherapy and potential radiosensitisation. British Journal of Radiology 86 20120601. (doi:10.1259/bjr. 20120601)

Lee CY, Lin Y, Bratman SV, Feng W, Kuo AH, Scheeren FA, Engreitz JM, Varma S, West RB \& Diehn M 2014 Neuregulin autocrine signaling promotes self-renewal of breast tumor-initiating cells by triggering HER2/HER3 activation. Cancer Research 74 341-352. (doi:10.1158/ 0008-5472.CAN-13-1055)

Lehmann BD, Bauer JA, Chen X, Sanders ME, Chakravarthy AB, Shyr Y \& Pietenpol JA 2011 Identification of human triple-negative breast cancer subtypes and preclinical models for selection of targeted therapies. Journal of Clinical Investigation 121 2750-2767. (doi:10.1172/JCI45014)

Lewis MT \& Visbal AP 2006 The hedgehog signaling network, mammary stem cells, and breast cancer: connections and controversies. Ernst Schering Foundation Symposium Proceedings 181-217.

Li Y, Welm B, Podsypanina K, Huang S, Chamorro M, Zhang X, Rowlands T, Egeblad M, Cowin P, Werb Z et al. 2003 Evidence that transgenes encoding components of the Wnt signaling pathway preferentially induce mammary cancers from progenitor cells. PNAS $\mathbf{1 0 0}$ 15853-15858. (doi:10.1073/pnas.2136825100)

Li X, Lewis MT, Huang J, Gutierrez C, Osborne CK, Wu MF, Hilsenbeck SG, Pavlick A, Zhang X, Chamness GC et al. 2008 Intrinsic resistance of tumorigenic breast cancer cells to chemotherapy. Journal of the National Cancer Institute 100 672-679. (doi:10.1093/jnci/djn123)

Li QQ, Xu JD, Wang WJ, Cao XX, Chen Q, Tang F, Chen ZQ, Liu XP \& Xu ZD 2009 Twist1-mediated adriamycin-induced epithelial-mesenchymal transition relates to multidrug resistance and invasive potential in breast cancer cells. Clinical Cancer Research 15 2657-2665. (doi:10.1158/1078-0432.CCR-08-2372)

Liu S, Dontu G, Mantle ID, Patel S, Ahn NS, Jackson KW, Suri P \& Wicha MS 2006 Hedgehog signaling and Bmi-1 regulate self-renewal of normal and malignant human mammary stem cells. Cancer Research 66 6063-6071. (doi:10.1158/0008-5472.CAN-06-0054)

Liu JC, Deng T, Lehal RS, Kim J \& Zacksenhaus E 2007 Identification of tumorsphere- and tumor-initiating cells in HER2/Neu-induced mammary tumors. Cancer Research 67 8671-8681. (doi:10.1158/ 0008-5472.CAN-07-1486)

Liu H, Patel MR, Prescher JA, Patsialou A, Qian D, Lin J, Wen S, Chang YF, Bachmann MH, Shimono Y et al. 2010 Cancer stem cells from human breast tumors are involved in spontaneous metastases in orthotopic mouse models. PNAS 107 18115-18120. (doi:10.1073/pnas. 1006732107)

Liu S, Ginestier C, Ou SJ, Clouthier SG, Patel SH, Monville F, Korkaya H, Heath A, Dutcher J, Kleer CG et al. 2011 Breast cancer stem cells are regulated by mesenchymal stem cells through cytokine networks. Cancer Research 71 614-624. (doi:10.1158/0008-5472. CAN-10-0538)

Liu S, Patel SH, Ginestier C, Ibarra I, Martin-Trevino R, Bai S, McDermott SP, Shang L, Ke J, Ou SJ et al. 2012 MicroRNA93 regulates proliferation and differentiation of normal and malignant breast stem cells. PLoS Genetics 8 e1002751. (doi:10.1371/journal.pgen.1002751)

Liu S, Cong Y, Wang D, Sun Y, Deng L, Liu Y, Martin-Trevino R, Shang L, McDermott Sean P, Landis Melissa D et al. 2014 Breast cancer stem cells transition between epithelial and mesenchymal states reflective of their normal counterparts. Stem Cell Reports 2 78-91. (doi:10.1016/ j.stemcr.2013.11.009)

Lo PK, Kanojia D, Liu X, Singh UP, Berger FG, Wang Q \& Chen H 2012 CD49f and CD61 identify Her2/neu-induced mammary tumor-initiating cells that are potentially derived from luminal progenitors and maintained by the integrin-TGF $\beta$ signaling. Oncogene 31 2614-2626. (doi:10.1038/onc.2011.439)

Lower EE, Glass EL, Bradley DA, Blau R \& Heffelfinger S 2005 Impact of metastatic estrogen receptor and progesterone receptor status on survival. Breast Cancer Research and Treatment 90 65-70. (doi:10.1007/ s10549-004-2756-z)

Lu W \& Li Y 2014 Salinomycin suppresses LRP6 expression and inhibits both Wnt/ $\beta$-catenin and mTORC1 signaling in breast and prostate cancer cells. Journal of Cellular Biochemistry 115 1799-1807. (doi:10.1002/jcb.24850)

Lu D, Choi MY, Yu J, Castro JE, Kipps TJ \& Carson DA 2011 Salinomycin inhibits Wnt signaling and selectively induces apoptosis in chronic lymphocytic leukemia cells. PNAS 108 13253-13257. (doi:10.1073/ pnas.1110431108)

Luo M, Fan H, Nagy T, Wei H, Wang C, Liu S, Wicha MS \& Guan JL 2009 Mammary epithelial-specific ablation of the focal adhesion kinase suppresses mammary tumorigenesis by affecting mammary cancer stem/progenitor cells. Cancer Research 69 466-474. (doi:10.1158/00085472.CAN-08-3078)

Luo M, Zhao X, Chen S, Liu S, Wicha MS \& Guan JL 2013 Distinct FAK activities determine progenitor and mammary stem cell characteristics. Cancer Research 73 5591-5602. (doi:10.1158/0008-5472. CAN-13-1351)

Ma J, Lanza DG, Guest I, Uk-Lim C, Glinskii A, Glinsky G \& Sell S 2012 Characterization of mammary cancer stem cells in the MMTV-PyMT mouse model. Tumour Biology 33 1983-1996. (doi:10.1007/s13277-012-0458-4)

MacDonald BT, Tamai K \& He X 2009 Wnt/ $\beta$-catenin signaling: components, mechanisms, and diseases. Developmental Cell 17 9-26. (doi:10.1016/j.devcel.2009.06.016)

Magnifico A, Albano L, Campaner S, Delia D, Castiglioni F, Gasparini P, Sozzi G, Fontanella E, Menard S \& Tagliabue E 2009 Tumor-initiating cells of HER2-positive carcinoma cell lines express the highest oncoprotein levels and are sensitive to trastuzumab. Clinical Cancer Research 15 2010-2021. (doi:10.1158/1078-0432.CCR-08-1327)

Mani SA, Guo W, Liao MJ, Eaton EN, Ayyanan A, Zhou AY, Brooks M, Reinhard F, Zhang CC, Shipitsin M et al. 2008 The epithelialmesenchymal transition generates cells with properties of stem cells. Cell 133 704-715. (doi:10.1016/j.cell.2008.03.027)

Marcato P, Dean CA, Pan D, Araslanova R, Gillis M, Joshi M, Helyer L, Pan L, Leidal A, Gujar S et al. 2011 Aldehyde dehydrogenase activity of breast cancer stem cells is primarily due to isoform ALDH1A3 and its expression is predictive of metastasis. Stem Cells 29 32-45. (doi:10.1002/ stem.563)

Marjanovic ND, Weinberg RA \& Chaffer CL 2013 Cell plasticity and heterogeneity in cancer. Clinical Chemistry 59 168-179. (doi:10.1373/ clinchem.2012.184655)

Marotta LLC, Almendro V, Marusyk A, Shipitsin M, Schemme J, Walker SR, Bloushtain-Qimron N, Kim JJ, Choudhury SA, Maruyama R et al. 2011 The JAK2/STAT3 signaling pathway is required for growth of 
CD44 + CD24 - stem cell-like breast cancer cells in human tumors. Journal of Clinical Investigation 121 2723-2735. (doi:10.1172/JCI44745)

Massarweh S, Osborne CK, Jiang S, Wakeling AE, Rimawi M, Mohsin SK, Hilsenbeck S \& Schiff R 2006 Mechanisms of tumor regression and resistance to estrogen deprivation and fulvestrant in a model of estrogen receptor-positive, HER-2/neu-positive breast cancer. Cancer Research 66 8266-8273. (doi:10.1158/0008-5472. CAN-05-4045)

Matsuda T, Nakamura T, Nakao K, Arai T, Katsuki M, Heike T \& Yokota T 1999 STAT3 activation is sufficient to maintain an undifferentiated state of mouse embryonic stem cells. EMBO Journal 18 4261-4269. (doi:10.1093/emboj/18.15.4261)

Maycotte P, Gearheart CM, Barnard R, Aryal S, Mulcahy Levy JM, Fosmire SP, Hansen RJ, Morgan MJ, Porter CC, Gustafson DL et al. 2014 STAT3-mediated autophagy dependence identifies subtypes of breast cancer where autophagy inhibition can be efficacious. Cancer Research 74 2579-2590. (doi:10.1158/0008-5472.CAN-13-3470)

Mayr C \& Bartel DP 2009 Widespread shortening of 3'UTRs by alternative cleavage and polyadenylation activates oncogenes in cancer cells. Cell 138 673-684. (doi:10.1016/j.cell.2009.06.016)

Meyer MJ, Fleming JM, Ali MA, Pesesky MW, Ginsburg E \& Vonderhaar BK 2009 Dynamic regulation of CD24 and the invasive, CD44posCD24neg phenotype in breast cancer cell lines. Breast Cancer Research 11 R82. (doi:10.1186/bcr2449)

Meyer MJ, Fleming JM, Lin AF, Hussnain SA, Ginsburg E \& Vonderhaar BK 2010 CD44posCD49fhiCD133/2hi defines xenograft-initiating cells in estrogen receptor-negative breast cancer. Cancer Research 70 4624-4633. (doi:10.1158/0008-5472.CAN-09-3619)

Moore N \& Lyle S 2011 Quiescent, slow-cycling stem cell populations in cancer: a review of the evidence and discussion of significance. Journal of Oncology 2011 pii: 396076. (doi:10.1155/2011/396076)

Moraes RC, Zhang X, Harrington N, Fung JY, Wu MF, Hilsenbeck SG, Allred DC \& Lewis MT 2007 Constitutive activation of smoothened (SMO) in mammary glands of transgenic mice leads to increased proliferation, altered differentiation and ductal dysplasia. Development 134 1231-1242. (doi:10.1242/dev.02797)

Morrison R, Schleicher SM, Sun Y, Niermann KJ, Kim S, Spratt DE, Chung $\mathrm{CH} \& \mathrm{Lu}$ B 2011 Targeting the mechanisms of resistance to chemotherapy and radiotherapy with the cancer stem cell hypothesis. Journal of Oncology 2011 941876. (doi:10.1155/2011/ 941876)

Mouw JK, Yui Y, Damiano L, Bainer RO, Lakins JN, Acerbi I, Ou G, Wijekoon AC, Levental KR, Gilbert PM et al. 2014 Tissue mechanics modulate microRNA-dependent PTEN expression to regulate malignant progression. Nature Medicine 20 360-367. (doi:10.1038/ nm.3497)

Muraoka-Cook RS, Dumont N \& Arteaga CL 2005 Dual role of transforming growth factor $\beta$ in mammary tumorigenesis and metastatic progression. Clinical Cancer Research 11 937s-943s.

Naumov GN, Townson JL, MacDonald IC, Wilson SM, Bramwell VH, Groom AC \& Chambers AF 2003 Ineffectiveness of doxorubicin treatment on solitary dormant mammary carcinoma cells or late-developing metastases. Breast Cancer Research and Treatment $\mathbf{8 2}$ 199-206. (doi:10.1023/B:BREA.0000004377.12288.3c)

Nguyen PL, Taghian AG, Katz MS, Niemierko A, Abi Raad RF, Boon WL, Bellon JR, Wong JS, Smith BL \& Harris JR 2008 Breast cancer subtype approximated by estrogen receptor, progesterone receptor, and HER-2 is associated with local and distant recurrence after breast-conserving therapy. Journal of Clinical Oncology 26 2373-2378. (doi:10.1200/JCO. 2007.14.4287)

Nie BMD 2012 Cancer stem cells and resistance to chemo and radio therapy. Frontiers in Bioscience: a Journal and Virtual Library 4 2142-2149.

Nusse R \& Varmus HE 1982 Many tumors induced by the mouse mammary tumor virus contain a provirus integrated in the same region of the host genome. Cell 31 99-109. (doi:10.1016/0092-8674(82)90409-3)
Park CC, Zhang H, Pallavicini M, Gray JW, Baehner F, Park CJ \& Bissell MJ 2006 Beta1 integrin inhibitory antibody induces apoptosis of breast cancer cells, inhibits growth, and distinguishes malignant from normal phenotype in three dimensional cultures and in vivo. Cancer Research 66 1526-1535. (doi:10.1158/0008-5472.CAN-05-3071)

Park CC, Zhang HJ, Yao ES, Park CJ \& Bissell MJ 2008 Beta1 integrin inhibition dramatically enhances radiotherapy efficacy in human breast cancer xenografts. Cancer Research 68 4398-4405. (doi:10.1158/ 0008-5472.CAN-07-6390)

Park SY, Lee HE, Li H, Shipitsin M, Gelman R \& Polyak K 2010 Heterogeneity for stem cell-related markers according to tumor subtype and histologic stage in breast cancer. Clinical Cancer Research 16 876-887. (doi:10.1158/1078-0432.CCR-09-1532)

Patrawala L, Calhoun T, Schneider-Broussard R, Zhou J, Claypool K \& Tang DG 2005 Side population is enriched in tumorigenic, stem-like cancer cells, whereas ABCG2 + and ABCG2 - cancer cells are similarly tumorigenic. Cancer Research 65 6207-6219. (doi:10.1158/0008-5472. CAN-05-0592)

Pece S, Tosoni D, Confalonieri S, Mazzarol G, Vecchi M, Ronzoni S, Bernard L, Viale G, Pelicci PG \& Di Fiore PP 2010 Biological and molecular heterogeneity of breast cancers correlates with their cancer stem cell content. Cell 140 62-73. (doi:10.1016/j.cell.2009.12.007)

Perou CM, Sorlie T, Eisen MB, van de Rijn M, Jeffrey SS, Rees CA, Pollack JR, Ross DT, Johnsen H, Akslen LA et al. 2000 Molecular portraits of human breast tumours. Nature 406 747-752. (doi:10.1038/35021093)

Phillips TM, McBride WH \& Pajonk F 2006 The response of CD24(-/low)/ CD44 + breast cancer-initiating cells to radiation. Journal of the National Cancer Institute 98 1777-1785. (doi:10.1093/jnci/djj495)

Prat A \& Perou CM 2011 Deconstructing the molecular portraits of breast cancer. Molecular Oncology 5 5-23. (doi:10.1016/j.molonc.2010.11.003)

Prat A, Parker J, Karginova O, Fan C, Livasy C, Herschkowitz J, He X \& Perou C 2010 Phenotypic and molecular characterization of the claudin-low intrinsic subtype of breast cancer. Breast Cancer Research 12 R68. (doi:10.1186/bcr2635)

Qiu M, Peng Q, Jiang I, Carroll C, Han G, Rymer I, Lippincott J, Zachwieja J, Gajiwala K, Kraynov E et al. 2013 Specific inhibition of Notch1 signaling enhances the antitumor efficacy of chemotherapy in triple negative breast cancer through reduction of cancer stem cells. Cancer Letters 328 261-270. (doi:10.1016/j.canlet.2012.09.023)

Quintas-Cardama A \& Verstovsek S 2013 Molecular pathways: Jak/STAT pathway: mutations, inhibitors, and resistance. Clinical Cancer Research 19 1933-1940. (doi:10.1158/1078-0432.CCR-12-0284)

Ramalho-Santos M, Yoon S, Matsuzaki Y, Mulligan RC \& Melton DA 2002 "Stemness": transcriptional profiling of embryonic and adult stem cells. Science 298 597-600. (doi:10.1126/science.1072530)

Raz R, Lee CK, Cannizzaro LA, d'Eustachio P \& Levy DE 1999 Essential role of STAT3 for embryonic stem cell pluripotency. PNAS 96 2846-2851. (doi:10.1073/pnas.96.6.2846)

Reim F, Dombrowski Y, Ritter C, Buttmann M, Hausler S, Ossadnik M, Krockenberger M, Beier D, Beier CP, Dietl J et al. 2009 Immunoselection of breast and ovarian cancer cells with trastuzumab and natural killer cells: selective escape of CD44high/CD24low/HER2low breast cancer stem cells. Cancer Research 69 8058-8066. (doi:10.1158/0008-5472. CAN-09-0834)

Ricardo S, Vieira AF, Gerhard R, Leitao D, Pinto R, Cameselle-Teijeiro JF, Milanezi F, Schmitt F \& Paredes J 2011 Breast cancer stem cell markers CD44, CD24 and ALDH1: expression distribution within intrinsic molecular subtype. Journal of Clinical Pathology 64 937-946. (doi:10.1136/jcp.2011.090456)

Rizzo P, Miao H, D’Souza G, Osipo C, Song LL, Yun J, Zhao H, Mascarenhas J, Wyatt D, Antico G et al. 2008 Cross-talk between notch and the estrogen receptor in breast cancer suggests novel therapeutic approaches. Cancer Research 68 5226-5235. (doi:10.1158/0008-5472. CAN-07-5744)

Rudas M, Filipits M, Taucher S, Stranzl T, Steger GG, Jakesz R, Pirker R \& Pohl G 2003 Expression of MRP1, LRP and Pgp in breast carcinoma 
patients treated with preoperative chemotherapy. Breast Cancer Research and Treatment 81 149-157. (doi:10.1023/A:1025751631115)

Scheel C \& Weinberg RA 2012 Cancer stem cells and epithelialmesenchymal transition: concepts and molecular links. Seminars in Cancer Biology 22 396-403. (doi:10.1016/j.semcancer.2012.04.001)

Scheel C, Eaton EN, Li SH, Chaffer CL, Reinhardt F, Kah KJ, Bell G, Guo W, Rubin J, Richardson AL et al. 2011 Paracrine and autocrine signals induce and maintain mesenchymal and stem cell states in the breast. Cell 145 926-940. (doi:10.1016/j.cell.2011.04.029)

Schneeweiss A, Chia S, Hickish T, Harvey V, Eniu A, Hegg R, Tausch C, Seo JH, Tsai YF, Ratnayake J et al. 2013 Pertuzumab plus trastuzumab in combination with standard neoadjuvant anthracycline-containing and anthracycline-free chemotherapy regimens in patients with HER2-positive early breast cancer: a randomized phase II cardiac safety study (TRYPHAENA). Annals of Oncology 24 2278-2284. (doi:10.1093/ annonc/mdt182)

Schott AF, Wicha M, Cristofanilli M, Ruffini P, McCanna S, Reuben JM \& Goldstein LJ 2012 Phase Ib pilot study to evaluate reparixin in combination with chemotherapy with weekly paclitaxel in patients with HER-2 negative metastatic breast cancer (MBC). Cancer Research 72 OT23-01. (doi:10.1158/0008-5472.SABCS12-OT2-3-01)

Schott AF, Landis MD, Dontu G, Griffith KA, Layman RM, Krop I, Paskett LA, Wong H, Dobrolecki LE, Lewis MT et al. 2013 Preclinical and clinical studies of $\gamma$ secretase inhibitors with docetaxel on human breast tumors. Clinical Cancer Research 19 1512-1524. (doi:10.1158/1078-0432.CCR11-3326)

Seguin L, Kato S, Franovic A, Camargo MF, Lesperance J, Elliott KC, Yebra M, Mielgo A, Lowy AM, Husain H et al. 2014 An integrin $\beta(3)$-KRAS-RalB complex drives tumour stemness and resistance to EGFR inhibition. Nature Cell Biology 16 457-468. (doi:10.1038/ncb2953)

Sheridan C, Kishimoto H, Fuchs R, Mehrotra S, Bhat-Nakshatri P, Turner C, Goulet R, Badve S \& Nakshatri H 2006 CD44+/CD24- breast cancer cells exhibit enhanced invasive properties: an early step necessary for metastasis. Breast Cancer Research 8 R59. (doi:10.1186/bcr1610)

Shimono Y, Zabala M, Cho RW, Lobo N, Dalerba P, Qian D, Diehn M, Liu H, Panula SP, Chiao E et al. 2009 Downregulation of miRNA-200c links breast cancer stem cells with normal stem cells. Cell 138 592-603. (doi:10.1016/j.cell.2009.07.011)

Shipitsin M, Campbell LL, Argani P, Weremowicz S, Bloushtain-Qimron N, Yao J, Nikolskaya T, Serebryiskaya T, Beroukhim R, Hu M et al. 2007 Molecular definition of breast tumor heterogeneity. Cancer Cell $\mathbf{1 1}$ 259-273. (doi:10.1016/j.ccr.2007.01.013)

Siegel PM, Shu W, Cardiff RD, Muller WJ \& Massague J 2003 Transforming growth factor $\beta$ signaling impairs Neu-induced mammary tumorigenesis while promoting pulmonary metastasis. PNAS $1008430-8435$. (doi:10.1073/pnas.0932636100)

Singh JK, Farnie G, Bundred NJ, Simoes BM, Shergill A, Landberg G, Howell SJ \& Clarke RB 2013 Targeting CXCR1/2 significantly reduces breast cancer stem cell activity and increases the efficacy of inhibiting HER2 via HER2-dependent and -independent mechanisms. Clinical Cancer Research 19 643-656. (doi:10.1158/1078-0432.CCR-12-1063)

Skov L, Beurskens FJ, Zachariae CO, Reitamo S, Teeling J, Satijn D, Knudsen KM, Boot EP, Hudson D, Baadsgaard O et al. 2008 IL-8 as antibody therapeutic target in inflammatory diseases: reduction of clinical activity in palmoplantar pustulosis. Journal of Immunology $\mathbf{1 8 1}$ 669-679. (doi:10.4049/jimmunol.181.1.669)

Slamon DJ, Clark GM, Wong SG, Levin WJ, Ullrich A \& McGuire WL 1987 Human breast cancer: correlation of relapse and survival with amplification of the HER-2/neu oncogene. Science 235 177-182. (doi:10.1126/science.3798106)

Stankic M, Pavlovic S, Chin Y, Brogi E, Padua D, Norton L, Massague J \& Benezra R 2013 TGF- $\beta$-Id1 signaling opposes Twist1 and promotes metastatic colonization via a mesenchymal-to-epithelial transition. Cell Reports 5 1228-1242. (doi:10.1016/j.celrep.2013.11.014)

Sun Y, Wang Y, Fan C, Gao P, Wang X, Wei G \& Wei J 2014 Estrogen promotes stemness and invasiveness of ER-positive breast cancer cells through Gli1 activation. Molecular Cancer 13 137. (doi:10.1186/ 1476-4598-13-137)

Tang B, Yoo N, Vu M, Mamura M, Nam JS, Ooshima A, Du Z, Desprez PY, Anver MR, Michalowska AM et al. 2007 Transforming growth factor- $\beta$ can suppress tumorigenesis through effects on the putative cancer stem or early progenitor cell and committed progeny in a breast cancer xenograft model. Cancer Research 67 8643-8652. (doi:10.1158/ 0008-5472.CAN-07-0982)

Torres J \& Watt FM 2008 Nanog maintains pluripotency of mouse embryonic stem cells by inhibiting NFкB and cooperating with Stat3. Nature Cell Biology 10 194-201. (doi:10.1038/ncb1680)

Tsukamoto AS, Grosschedl R, Guzman RC, Parslow T \& Varmus HE 1988 Expression of the int-1 gene in transgenic mice is associated with mammary gland hyperplasia and adenocarcinomas in male and female mice. Cell 55 619-625. (doi:10.1016/0092-8674(88)90220-6)

Turton NJ, Judah DJ, Riley J, Davies R, Lipson D, Styles JA, Smith AG \& Gant TW 2001 Gene expression and amplification in breast carcinoma cells with intrinsic and acquired doxorubicin resistance. Oncogene $\mathbf{2 0}$ 1300-1306. (doi:10.1038/sj.onc.1204235)

Usary J, Zhao W, Darr D, Roberts PJ, Liu M, Balletta L, Karginova O, Jordan J, Combest A, Bridges A et al. 2013 Predicting drug responsiveness in human cancers using genetically engineered mice. Clinical Cancer Research 19 4889-4899. (doi:10.1158/1078-0432.CCR-13-0522)

Vadakkan TJ, Landua JD, Bu W, Wei W, Li F, Wong STC, Dickinson ME, Rosen JM, Lewis MT \& Zhang M 2014 Wnt-responsive cancer stem cells are located close to distorted blood vessels and not in hypoxic regions in a p53-null mouse model of human breast cancer. Stem cells Translational Medicine 3 857-866. (doi:10.5966/sctm.2013-0088)

Vaillant F, Asselin-Labat ML, Shackleton M, Forrest NC, Lindeman GJ \& Visvader JE 2008 The mammary progenitor marker CD61/ß3 integrin identifies cancer stem cells in mouse models of mammary tumorigenesis. Cancer Research 68 7711-7717. (doi:10.1158/0008-5472. CAN-08-1949)

Vassilopoulos A, Wang RH, Petrovas C, Ambrozak D, Koup R \& Deng CX 2008 Identification and characterization of cancer initiating cells from BRCA1 related mammary tumors using markers for normal mammary stem cells. International Journal of Biological Sciences 4 133-142. (doi:10.7150/ijbs.4.133)

Visbal AP, LaMarca HL, Villanueva H, Toneff MJ, Li Y, Rosen JM \& Lewis MT 2011 Altered differentiation and paracrine stimulation of mammary epithelial cell proliferation by conditionally activated Smoothened. Developmental Biology 352 116-127. (doi:10.1016/j.ydbio.2011.01.025)

Visvader JE \& Lindeman GJ 2012 Cancer stem cells: current status and evolving complexities. Cell Stem Cell 10 717-728. (doi:10.1016/j.stem. 2012.05.007)

Wang Y, Waters J, Leung ML, Unruh A, Roh W, Shi X, Chen K, Scheet P, Vattathil S, Liang H et al. 2014a Clonal evolution in breast cancer revealed by single nucleus genome sequencing. Nature 512 155-160. (doi:10.1038/nature13600)

Wang CC, Bajikar SS, Jamal L, Atkins KA \& Janes KA 2014b A time- and matrix-dependent TGFBR3-JUND-KRT5 regulatory circuit in single breast epithelial cells and basal-like premalignancies. Nature Cell Biology 16 345-356. (doi:10.1038/ncb2930)

Wei W, Tweardy DJ, Zhang M, Zhang X, Landua J, Petrovic I, Bu W, Roarty K, Hilsenbeck SG, Rosen JM et al. 2014 STAT3 signaling is activated preferentially in tumor-initiating cells in claudin-low models of human breast cancer. Stem Cells 32 3571-3582. (doi:10.1002/stem.1752)

Woodward WA, Chen MS, Behbod F, Alfaro MP, Buchholz TA \& Rosen JM $2007 \mathrm{WNT} / \beta$-catenin mediates radiation resistance of mouse mammary progenitor cells. PNAS 104 618-623. (doi:10.1073/pnas. 0606599104)

Xiang L, Su P, Xia S, Liu Z, Wang Y, Gao P \& Zhou G 2011 ABCG2 is associated with HER-2 expression, lymph node metastasis and clinical stage in breast invasive ductal carcinoma. Diagnostic Pathology 690. (doi:10.1186/1746-1596-6-90) 
Xu X, Kasembeli MM, Jiang X, Tweardy BJ \& Tweardy DJ 2009 Chemical probes that competitively and selectively inhibit Stat3 activation. PLoS ONE 4 e4783. (doi:10.1371/journal.pone.0004783)

Yamamoto M, Taguchi Y, Ito-Kureha T, Semba K, Yamaguchi N \& Inoue J

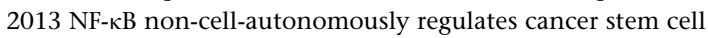
populations in the basal-like breast cancer subtype. Nature Communications 42299.

Yu H \& Jove R 2004 The STATs of cancer - new molecular targets come of age. Nature Reviews. Cancer 4 97-105. (doi:10.1038/nrc1275)

Yu F, Yao H, Zhu P, Zhang X, Pan Q, Gong C, Huang Y, Hu X, Su F, Lieberman J et al. 2007 let-7 regulates self renewal and tumorigenicity of breast cancer cells. Cell 131 1109-1123. (doi:10.1016/ j.cell.2007.10.054)

Zeng YA \& Nusse R 2010 Wnt proteins are self-renewal factors for mammary stem cells and promote their long-term expansion in culture. Cell Stem Cell 6 568-577. (doi:10.1016/j.stem.2010.03.020)

Zhang M, Behbod F, Atkinson RL, Landis MD, Kittrell F, Edwards D, Medina D, Tsimelzon A, Hilsenbeck S, Green JE et al. 2008
Identification of tumor-initiating cells in a p53-null mouse model of breast cancer. Cancer Research 68 4674-4682. (doi:10.1158/0008-5472. CAN-07-6353)

Zhang M, Atkinson RL \& Rosen JM 2010 Selective targeting of radiationresistant tumor-initiating cells. PNAS 107 3522-3527. (doi:10.1073/ pnas.0910179107)

Zhou J, Wulfkuhle J, Zhang H, Gu P, Yang Y, Deng J, Margolick JB, Liotta LA, Petricoin E \& Zhang Y 2007 Activation of the PTEN/mTOR/STAT3 pathway in breast cancer stem-like cells is required for viability and maintenance. PNAS 104 16158-16163. (doi:10.1073/ pnas.0702596104)

Zhu Y, Li F, Vadakkan TJ, Zhang M, Landua J, Wei W, Ma J, Dickinson ME, Rosen JM, Lewis MT et al. 2013 Three-dimensional vasculature reconstruction of tumour microenvironment via local clustering and classification. Interface Focus 3 20130015. (doi:10.1098/rsfs.2013.0015) Zielske SP, Spalding AC, Wicha MS \& Lawrence TS 2011 Ablation of breast cancer stem cells with radiation. Translational Oncology 4 227-233. (doi:10.1593/tlo.10247)

Received in final form 30 March 2015

Accepted 7 April 2015

Made available online as an Accepted Preprint

15 April 2015
(C) 2015 Society for Endocrinology Printed in Great Britain
Published by Bioscientifica Ltd. 